\title{
The Design of Organometallic Ruthenium Arene Anticancer Agents
}

\author{
Sarah J. Dougan ${ }^{\mathrm{a}}$ and Peter J. Sadlerb
}

\begin{abstract}
Organometallic half-sandwich Rull anticancer complexes of the type $\left[\left(\eta^{6} \text {-arene }\right) \mathrm{Ru}(\mathrm{YZ}) \mathrm{X}\right]^{\mathrm{n}}$ can exhibit interesting anticancer activity. We review the comparative aqueous solution chemistry (hydrolysis rates, $\mathrm{pK}_{\mathrm{a}}$ values of aqua complexes), cancer cell cytotoxicities, cross-resistance, reactivity towards nucleobases, DNA and important biomolecules for complexes containing various arenes, $\mathrm{N}, \mathrm{N}-$ or $\mathrm{N}, \mathrm{O}-$ or $\mathrm{O}, \mathrm{O}$-chelating ligands as $\mathrm{YZ}$, and monodentate leaving groups $\mathrm{X}$. We show that the choice of these ligands can have a dramatic effect on reactivity. The same is true for analogous Os" arene complexes. The interpretation of structure-activity relationships requires an understanding of reactions of these organometallic complexes under biological test conditions.
\end{abstract}

Keywords: Anticancer · Arene · Osmium · Organometallic complexes · Ruthenium

\section{Introduction}

\subsection{Ruthenium Complexes as Potential Anticancer Agents}

The anticancer properties of ruthenium were first reported in 1976 when the $\mathrm{Ru}^{\mathrm{III}}$ compound fac- $\mathrm{Ru}\left(\mathrm{NH}_{3}\right)_{3} \mathrm{Cl}_{3}$ was found to induce filamentous growth of $E$. coli at a concentration comparable to the concentration required for cisplatin to produce similar effects. ${ }^{[1]}$ This compound, and analogues such as cis-[ $\left[\mathrm{RuCl}_{2}\left(\mathrm{NH}_{3}\right)_{4}\right]$ demonstrated the potential anticancer activity of ruthenium complexes. However, they were too insoluble for pharmacological use. ${ }^{[2]}$

Since this discovery, there have been several other reports of ruthenium complexes which exhibit anticancer activity, most of which contain $\mathrm{Ru}^{\mathrm{III}}$. Perhaps two of the most exciting $\mathrm{Ru}^{\mathrm{III}}$ anticancer compounds are currently imidazolium trans-te trachlorodimethylsulfoxideimidazoleruthe nate(III), NAMI-A, and indazolium transtetrachlorobis( $1 \mathrm{H}$-indazole)ruthenate(III), KP-1019, since both compounds have entered clinical trials ${ }^{[3,4]}$ as anticancer drugs.

${ }^{*}$ Correspondence: Prof. P. J. Sadler ${ }^{b}$

Tel.: +442476523818

Fax: +442476523819

E-Mail: P.J. Sadler@warwick.ac.uk

aschool of Chemistry

The University of Edinburgh

West Mains Road

Edinburgh, EH9 3JJ, UK

bDepartment of Chemistry

University of Warwick

Coventry, CV4 7AL, UK
It has been suggested that $\mathrm{Ru}^{\mathrm{III}}$ complexes are 'activated by reduction' in vivo to $\mathrm{Ru}^{\mathrm{II}}$ to coordinate more rapidly to biomolecules ${ }^{[5]}$ due to the increased lability of $\mathrm{Ru}^{\mathrm{II}}-\mathrm{Cl}$ bonds. ${ }^{[3]}$ There is a lower oxygen content and more acidic $\mathrm{pH}$ in tumours than in normal tissue and so the production of $\mathrm{Ru}^{\mathrm{II}}$ relative to $\mathrm{Ru}^{\mathrm{III}}$ should be favoured in tumours. ${ }^{[5]}$

\subsection{Ruthenium(II) Complexes}

Because $\mathrm{Ru}^{\mathrm{II}}$ may be an active form of ruthenium, there is now an increased effort into research on the anticancer activity of $\mathrm{Ru}^{\mathrm{II}}$ complexes. Early work on ruthenium(II) complexes, for example $\quad$ is $-\left[\mathrm{RuCl}_{2}(\mathrm{DMSO})_{4}\right]$ and trans$\left[\mathrm{RuCl}_{2}(\mathrm{DMSO})_{4}\right]^{[6-8]}$ showed that $\mathrm{Ru}^{\mathrm{II}}$ complexes are potentially interesting in the design of new drugs.

In this review we will focus on organometallic ruthenium(II) complexes of the type $\left[\left(\eta^{6}\right.\right.$-arene $\left.) \mathrm{Ru}(\mathrm{XY}) \mathrm{Z}\right](\mathrm{XY}=$ bi-dentate ligand or two mono-dentate ligands, $\mathrm{Z}$ typically a halide) where $X Y$ are nitrogen or oxygen ligands (NN, NO, OO, N). Other active areas of research into the anticancer activity of $\mathrm{Ru}^{\mathrm{II}}$ arenes include complexes such as $\left[\left(\eta^{6}\right.\right.$-arene $) \mathrm{RuCl}_{2}$ (phosphine)] which contain phosphorus ligands such as pta (pta $=$ 1,3,5-triaza-7-phosphaadamantane). ${ }^{[9]}$

\section{Ruthenium(II) Arene Complexes as Anticancer Agents}

\subsection{General Structure and Reactivity}

The general structure of the $\mathrm{Ru}^{\mathrm{II}}$ arene complexes described here is shown in Scheme 1. All complexes contain an $\eta^{6}$ arene occupying three coordination sites, a chelating ligand occupying two and a mono-dentate ligand occupying the final site.

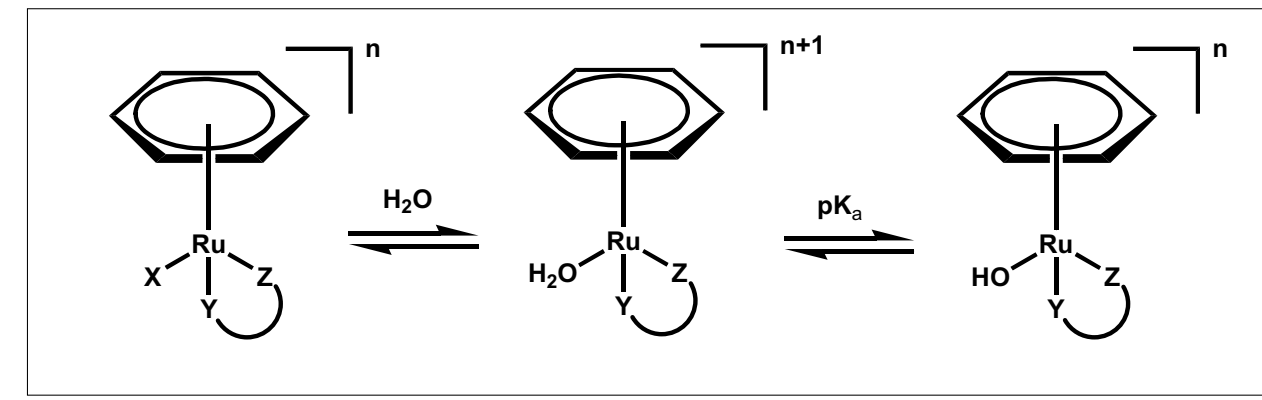

Scheme 1. General structure of Rull arene anticancer complexes containing an $\eta^{6}$ arene, a chelating ligand $Y Z$ and a monodentate labile ligand $X$ that provides a reactive site for the molecule. In water, the $\mathrm{Ru}-\mathrm{X}$ bond is subject to hydrolysis to generate the corresponding aqua adduct which can be deprotonated (depending on the $\mathrm{pK}_{\mathrm{a}}$ ) to give the hydroxo form. 
Depending on the nature of the chelated ligand, these complexes are either neutral or positively charged (and isolated as salts). Variations to all three ligand types can be achieved, so there is a great scope for the synthesis of a vast library of potential anticancer complexes. There are several synthetic routes to the complexes and these have recently been summarized.[10]

The mechanism of cytotoxic action of $\mathrm{Ru}^{\mathrm{II}}$ arenes is generally thought to involve hydrolysis of the $\mathrm{Ru}-\mathrm{X}$ bond generating an active $\mathrm{Ru}-\mathrm{OH}_{2}$ species. This species will exist over a range of $\mathrm{pH}$ values, but above the $\mathrm{pH}=\mathrm{pK}_{\mathrm{a}}$ value (the $\mathrm{pH}$ at which $50 \%$ of the species exists as $\mathrm{Ru}-\mathrm{OH}_{2}$ and $\mathrm{Ru}-\mathrm{OH}$ through deprotonation of the $\mathrm{H}_{2} \mathrm{O}$ ligand) the hydroxo $\mathrm{Ru}-\mathrm{OH}$ species will predominate, and this complex is usually considered to be a less reactive species (Scheme 1). Hydroxide is a less labile ligand than water and hence will not be as easily displaced by biomolecule targets. Thus ideally $\mathrm{pK}_{\mathrm{a}}$ values of $c a . \mathrm{pH}>7$ for aqua adducts should ensure that the active species predominates at physiological $\mathrm{pH}$ (7.2-7.4). Furthermore the rate of hydrolysis is important; if the complexes hydrolyse too fast they may not reach the target site.

Hydrolysis can be suppressed extracellularly due to high $\left[\mathrm{Cl}^{-}\right](\mathrm{ca} .0 .1 \mathrm{M})$ but becomes possible after the complex enters the cells due a lower $\left[\mathrm{Cl}^{-}\right](\mathrm{ca} .4-25 \mathrm{mM})$ found intracellularly. We thus obtain selective activation inside the cell. The primary cellular target for $\mathrm{Ru}^{\mathrm{II}}$ arenes, as for many metal-based drugs is thought to be DNA ${ }^{[11]}$ and so factors affecting DNA binding such as rate and extent of binding and non-covalent interactions such as hydrogen bonding and DNA intercalation become important.

\subsection{Ruthenium-Arene Bonding}

The structural and electronic features of metal-arene bonding have been thoroughly reviewed. ${ }^{[12]}$ The arene is considered as a $\pi$-acid $/ \pi$-acceptor ligand towards ruthenium. Evidence for this comes from

i) arene ${ }^{1} \mathrm{H}$ proton resonances which, upon arene coordination to $\mathrm{Ru}^{\mathrm{II}}$ shift to a lower frequency due to increased electron density, ${ }^{[13]}$ and

ii) from UV-Vis spectroscopic observations. ${ }^{[14]}$

$\mathrm{Ru}$-arene bonds are generally stable towards hydrolysis, although recently we have reported that the photochemical displacement of the arene can occur in aqueous solution for dinuclear complexes such as $\left[\left\{\left(\eta^{6} \text {-indan }\right) \mathrm{RuCl}\right\}_{2}(\mu-2,3-\mathrm{dpp})\right]$ $\left(\mathrm{PF}_{6}\right)_{2},{ }^{[15]}$ and arene lability can be induced by the presence of strong $\pi$-acceptor ligands bound elsewhere in the complex.

The aqueous solution chemistry of $\left[\left(\eta^{6} \text {-benzene }\right) \mathrm{Ru}\left(\mathrm{OH}_{2}\right)_{3}\right]^{2+}$ compared to $\left[\mathrm{Ru}\left(\mathrm{OH}_{2}\right)_{6}\right]^{2+}$ has shown that water exchange rates are three orders of magnitude

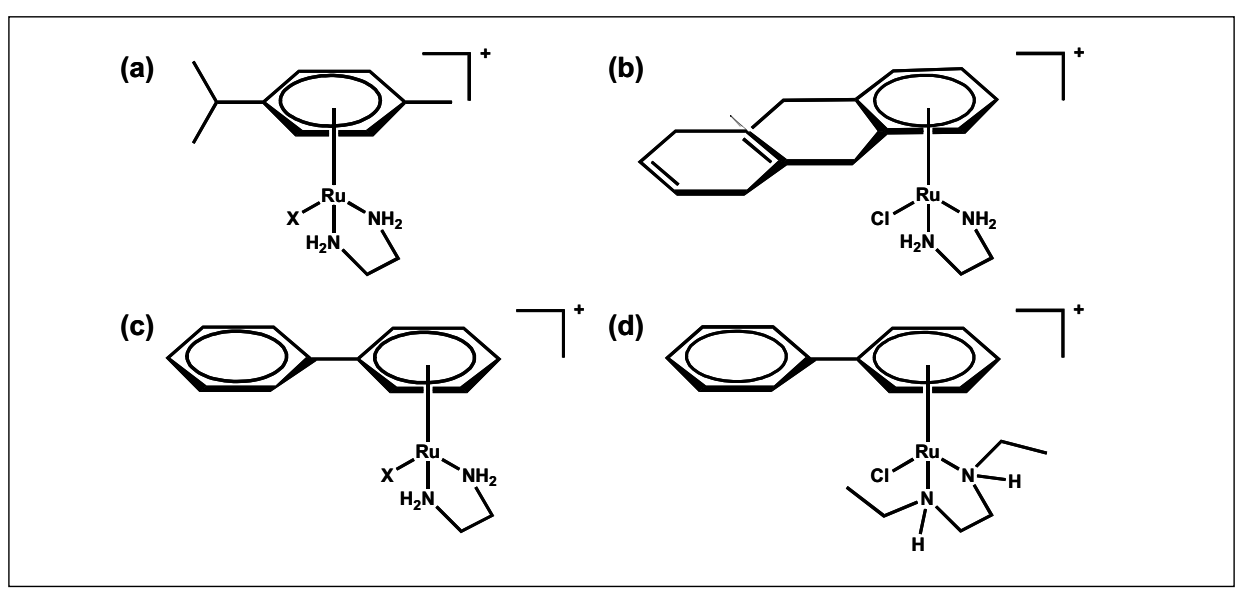

Fig. 1. Molecular Structures of (a) $\left[\left(\eta^{6}-p \text {-cymene) } \mathrm{Ru}(\mathrm{en}) \mathrm{X}\right]^{+},(\mathrm{b})\left[\left(\eta^{6} \text {-tetrahydronaphthalene) } \mathrm{Ru}(\mathrm{en}) \mathrm{Cl}\right]^{+}\right.\right.$, (c) $\left[\left(\eta^{6}\right.\right.$-biphenyl)Ru(en)X] and (d) $\left[\left(\eta^{6} \text {-biphenyl)Ru(en-Et)Cl }\right]^{+}\right.$

faster for $\left[\left(\eta^{6} \text {-benzene }\right) \mathrm{Ru}\left(\mathrm{OH}_{2}\right)_{3}\right]^{2+}$ and this increase in rate has been attributed to a change in the transition state properties of the reaction due to the incorporation of the benzene ligand and reaction via an I (interchange) mechanism. ${ }^{[13]}$

\section{Ruthenium(II) Arene Complexes Containing Chelating $\sigma$-Donor Nitrogen Ligands}

\subsection{Initial Work}

Initially the anticancer activity of $\mathrm{Ru}^{\mathrm{II}}$ arenes containing chelating nitrogen ligands such as ethylenediamine (en) or N-ethylethylenediamine (en-Et) (Fig. 1) was evaluated. ${ }^{[16]}$ Several derivatives such as $\quad\left[\left(\eta^{6}-p \text {-cymene }\right) \mathrm{Ru}(\mathrm{en}) \mathrm{Cl}\right]^{+}, \quad\left[\left(\eta^{6}-p\right.\right.$ cymene $) \mathrm{Ru}(\mathrm{en}) \mathrm{I}]^{+}, \quad\left[\left(\eta^{6}\right.\right.$-biphenyl $) \mathrm{Ru}(\mathrm{en})$ $\mathrm{Cl}]^{+}$and $\left[\left(\eta^{6} \text {-biphenyl }\right) \mathrm{Ru}(\mathrm{en}-\mathrm{Et}) \mathrm{Cl}\right]^{+}$, all inhibited the growth of the A2780 cancer cells with $\mathrm{IC}_{50}$ values of between 6-9 $\mu \mathrm{M}$, comparable to the clinically-used anticancer drug carboplatin $(6 \mu \mathrm{M})$. Furthermore complexes containing more hydrophobic arenes such as $\left[\left(\eta^{6}\right.\right.$-tetrahydronaphthalene $)$ $\mathrm{Ru}(\mathrm{en}) \mathrm{Cl}]^{+}$were active with $\mathrm{IC}_{50}$ values equipotent with cisplatin $(0.6 \mu \mathrm{M}){ }^{[17]}$ Interestingly ruthenium complexes containing mono-dentate ligands such as $\left[\left(\eta^{6}-p \text {-cymene }\right) \mathrm{Ru}\left(\mathrm{CH}_{3} \mathrm{CN}\right)_{2} \mathrm{Cl}\right]^{+}$and $\left[\left(\eta^{6}-\right.\right.$ $p$-cymene $\left.) \mathrm{Ru}(\text { isonicotinamde })_{2} \mathrm{Cl}\right]^{+}$were inactive towards the $\mathrm{A} 2780$ cancer cell line $\left(\mathrm{IC}_{50}\right.$ values $\left.>150 \mu \mathrm{M}\right)$ indicating that a bi-dentate chelating ligand is required for cancer cell cytotoxicity. Structure-activity relationships thus showed that the most active complexes contain stable bi-dentate chelating ligands, a more hydrophobic arene ligand and a single ligand exchange centre (e.g. halide).

In water, $\left[\left(\eta^{6}-p \text {-cymene }\right) \mathrm{Ru}(\mathrm{en}) \mathrm{Cl}\right]^{+}$ undergoes rapid aquation to form $\left[\left(\eta^{6}-p\right.\right.$ cymene) $\left.\mathrm{Ru}(\mathrm{en}) \mathrm{H}_{2} \mathrm{O}\right]^{2+}$. This hydrolysis is largely suppressed in $0.1 \mathrm{M} \mathrm{NaCl} .^{[16]}$ Reaction of $\left[\left(\eta^{6}-p \text {-cymene }\right) \mathrm{Ru}(\mathrm{en}) \mathrm{Cl}\right]^{+}$with the
DNA 14-mer $d\left(A_{1} T_{2} A_{3} C_{4} A_{5} T_{6} G_{7} G_{8} T_{9} A_{1}\right.$ ${ }_{0} \mathrm{C}_{11} \mathrm{~A}_{12} \mathrm{~T}_{13} \mathrm{~A}_{14}$ ) in varying ratios showed that $\left[\left(\eta^{6}-p \text {-cymene }\right) \mathrm{Ru}(\mathrm{en}) \mathrm{H}_{2} \mathrm{O}\right]^{2+}$ ruthenates DNA specifically at guanine residues to from two mono-ruthenated adducts at G7 and G8, as well as species di-ruthenated at both G7 and G8. ${ }^{[16]}$

\subsection{Ethylenediamine (en) Ligands} 3.2.1. Structure-Activity Relationships (SAR)

In general, introduction of polar substituents into the coordinated benzene ring in $\left[\left(\eta^{6}\right.\right.$-arene $\left.) \mathrm{Ru}(\mathrm{en}) \mathrm{Cl}\right] \mathrm{PF}_{6}$ complexes lowers their cytotoxicity towards A2780 human ovarian cancer cells. ${ }^{[10]}$ Thus for monosubstituted benzenes, the activity follows the order of substituents $\mathrm{OPh}(18 \mu \mathrm{M})>\mathrm{H}$ $(20 \mu \mathrm{M})>\mathrm{CONH}_{2}(33 \mu \mathrm{M})>>$ COOEt $(52$ $\mu \mathrm{M}), \mathrm{COPh}(55 \mu \mathrm{M}), \mathrm{COOMe}(56 \mu \mathrm{M}), \mathrm{Br}$ $(60 \mu \mathrm{M})>>\mathrm{CH}_{2} \mathrm{OH}(>100 \mu \mathrm{M})$. On the other hand, benzene arenes substituted with relatively non-polar sterically-demanding alkyl, phenyl or benzyl groups are much more potent with $\mathrm{IC}_{50}$ values as low as 3 $\mu \mathrm{M}$.

The activity against the same cell line for analogous complexes in which the arene is a fused system has also been evaluated. ${ }^{[10]}$ In general, complexes with $\mathrm{Ru}^{\mathrm{II}}$ coordinated to partially-saturated five-, six- or seven-membered cyclic hydrocarbons all show good activity with the exception of the cyclophane arene. The order of potency is tetrahydroanthracene $(0.4 \mu \mathrm{M}),>5$,6-dihydrophenanthracene $(1 \mu \mathrm{M})$, fluorene $(2$ $\mu \mathrm{M})$, dihydroanthrancene $(2 \mu \mathrm{M})>$ dibenzosuberane $(8 \mu \mathrm{M})$, indan $(8 \mu \mathrm{M})>$ tetralin $(20 \mu \mathrm{M})>>$ cyclophane $(>100 \mu \mathrm{M})$. In general the trend is that cytotoxicity increases with arene ring size in these cases, as described earlier.

\subsubsection{Aqueous Solution Chemistry}

Hydrolysis of the $\mathrm{Ru}-\mathrm{X}$ bond is thought to be central to the cytotoxicity of $\mathrm{Ru}^{\mathrm{II}}$ arene 
complexes since it is this step that activates the complex for potential binding to DNA or other possible cellular targets. The rates of hydrolysis of $\left[\left(\eta^{6} \text {-bip }\right) \mathrm{Ru}(\mathrm{en}) \mathrm{Cl}\right]^{+},\left[\left(\eta^{6}\right.\right.$-tha $)$ $\mathrm{Ru}(\mathrm{en}) \mathrm{Cl}]^{+}$and $\left[\left(\eta^{6} \text {-dha }\right) \mathrm{Ru}(\mathrm{en}) \mathrm{Cl}\right]^{+}$(bip = biphenyl, tha $=$ tetrahydroanthracene, dha $=$ dihydroanthracene) are essentially independent of ionic strength and increase with the size of the arene: $3.95 \times 10^{-3} \mathrm{~s}^{-1}, \mathrm{t}_{1 / 2}=$ 2.92 min for arene = bip, $6.84 \times 10^{-3} \mathrm{~s}^{-1}, \mathrm{t}_{1 / 2}$ $=1.69 \mathrm{~min}$ for arene $=$ tha and $6.49 \times 10^{-3}$ $\mathrm{s}^{-1}, \mathrm{t}_{1 / 2}=1.78 \mathrm{~min}$ for arene $=\mathrm{dha}(310 \mathrm{~K}$, $0.1 \mathrm{M} \mathrm{NaClO}_{4}, 0.3 \mathrm{mM}$ bip, $0.5 \mathrm{mM}$ tha and dha complexes). ${ }^{[18]}$ The rates of the corresponding anation reactions (replacement of $\mathrm{H}_{2} \mathrm{O}$ by $\mathrm{Cl}^{-}$) were also studied and decrease by about two-fold on increasing the ionic strength from 0.015 to $0.5 \mathrm{M} \mathrm{NaClO}_{4}$. This decrease is expected on the basis of the Brønsted equation, i.e. that the rate constant is expected to be independent of the ionic strength when one of the reactants remains uncharged, whereas the rate constant decreases with ionic strength if the charges on the two ions are of opposite sign. ${ }^{[19]}$ The anation reactions were rapid, reaching equilibrium within $c a$. 100-1600 s. Generally the anation reactions of the $\left[\left(\eta^{6}\right.\right.$-tha) $\left.\mathrm{Ru}(\mathrm{en}) \mathrm{H}_{2} \mathrm{O}\right]^{2+}$ and $\left[\left(\eta^{6} \text {-dha }\right) \mathrm{Ru}(\mathrm{en}) \mathrm{H}_{2} \mathrm{O}\right]^{2+}$ complexes were about 2.5 fold faster than $\left[\left(\eta^{6} \text {-bip) } \mathrm{Ru}(\text { en }) \mathrm{H}_{2} \mathrm{O}\right]^{2+}\right.$.

The $\mathrm{pK}_{\mathrm{a}}$ of the aqua complexes $\left[\left(\eta^{6}-\right.\right.$ bip) $\left.\mathrm{Ru}(\mathrm{en}) \mathrm{H}_{2} \mathrm{O}\right]^{2+},\left[\left(\eta^{6} \text {-dha }\right) \mathrm{Ru}(\mathrm{en}) \mathrm{H}_{2} \mathrm{O}\right]^{2+}$ and $\left[\left(\eta^{6} \text {-tha }\right) \mathrm{Ru}(\text { en }) \mathrm{H}_{2} \mathrm{O}\right]^{2+}$ are $7.71,7.89$ and 8.01 respectively. ${ }^{[18]}$ Thus in the blood plasma, where the chloride concentration is high ( $c a .0 .14 \mathrm{M})$ all three complexes exist largely $(>89 \%)$ in this inactive chlorido form. Upon entering the cytoplasm and nucleus, the chloride concentrations drop to ca. 23 and $4 \mathrm{mM}$, respectively. Hence the extent of aquation is predicted to increase from about $30 \%$ in the cytoplasm to about $70 \%$ in the nucleus. This would represent an activation mechanism for these chloro complexes inside the cytoplasm/nucleus. Interestingly, only a small amount of $\mathrm{Ru}-\mathrm{OH}$ hydroxo adducts (average $<10 \%$ of total ruthenium) is predicted to exist inside cells due to the high $\mathrm{pK}_{\mathrm{a}}$ value of the aqua adducts. This becomes important for DNA binding, since the $\mathrm{Ru}-\mathrm{OH}$ bond is found to be less reactive towards DNA nucleobases compared to $\mathrm{Ru}-\mathrm{OH}_{2}$ (vide supra).

Density functional theory calculations ${ }^{[20]}$ for aquation of [( $\eta^{6}$-benzene $)$ $\mathrm{Ru}($ en $) \mathrm{X}]^{+}, \mathrm{X}=\mathrm{Cl}^{-}, \mathrm{Br}^{-}, \mathrm{I}^{-}, \mathrm{N}_{3}^{-}$suggests that the aquation proceeds via a concerted interchange pathway and does not appear to be strongly associatively or dissociatively activated. The reaction barriers and overall reaction energies for aquation follow the order $\mathrm{Br}<\mathrm{Cl}<\mathrm{I}<\mathrm{N}_{3}$. The reactions appear to occur nearer the $\mathrm{I}_{\mathrm{a}}$ (interchange-associative) mechanistic continuum rather than the $I_{d}$ (interchange-dissociative mechanism). On the basis of electronegativity, the $\mathrm{N}_{3}$ complex would be expected to hydrolyze at a rate between the $\mathrm{Cl}^{-}$and $\mathrm{Br}^{-}$analogues but a much slower rate is observed. The lower rate is ascribed to the increased steric bulk of this polyatomic pseudohalide; an $\mathrm{I}_{\mathrm{a}}$ substitution is more influenced by steric factors than an $I_{d}$ pathway. Furthermore, the electron-accepting effect of the strong $\pi$-acid arene ligands is thought to be responsible for the shift towards a more associative $\mathrm{I}_{\mathrm{a}}$ pathway. $\mathrm{Ru} \mathrm{u}^{\mathrm{III}}$ complexes usually react via associative pathways ${ }^{[21]}$ whereas $\mathrm{Ru}^{\mathrm{II}}$ complexes are more suited to dissociative mechanisms. ${ }^{[22]}$ The $\pi$-acid arene accepts electron density from ruthenium to produce a higher charge on the metal. Thus $\mathrm{Ru}^{\mathrm{II}}$ in $\left\{\left(\eta^{6}\right.\right.$-arene $\left.\left.) \mathrm{Ru}\right]\right\}^{2+}$ may behave more like a $\mathrm{Ru}^{\mathrm{III}}$ centre.

Good correlations between hydrolysis rates, hydrolysis equilibrium and cytotoxicity have been observed for the ruthenium complexes $\left[\left(\eta^{6}-\mathrm{hmb}\right) \mathrm{Ru}(\mathrm{en}) \mathrm{X}\right]^{+}, \mathrm{hmb}=$ hexamethylbenzene[20] (Fig. 2). In general, a faster hydrolysis rate and a high percentage of aqua species at equilibrium correlated with good cytotoxicity towards the A2780 human ovarian cancer cell line. An exception is for the complex $\left[\left(\eta^{6}-\mathrm{hmb}\right)\right.$ $\mathrm{Ru}(\mathrm{en}) \mathrm{SPh}]^{+}$which hydrolyses very slowly and to a low extent. This complex may be activated by oxidation of bound $\mathrm{SPh}$ to the sulfenate or sulfinate by oxygen, since reactions of $\mathrm{Ru}^{\mathrm{II}}$ arenes with GSH show similar behaviour (vide infra).

\subsubsection{Guanine Binding}

The interaction of $\left[\left(\eta^{6}\right.\right.$-arene $) \mathrm{Ru}(\mathrm{en})$ $\mathrm{Cl}]^{+}$complexes $($arene $=$biphenyl, tetrahydronapthalene, dihydronapthalene) and guanine DNA derivatives 9-ethylgusnine $(9 \mathrm{EtG})$, guanosine and 5-guanosine monophosphate (5-GMP) has been studied ex-

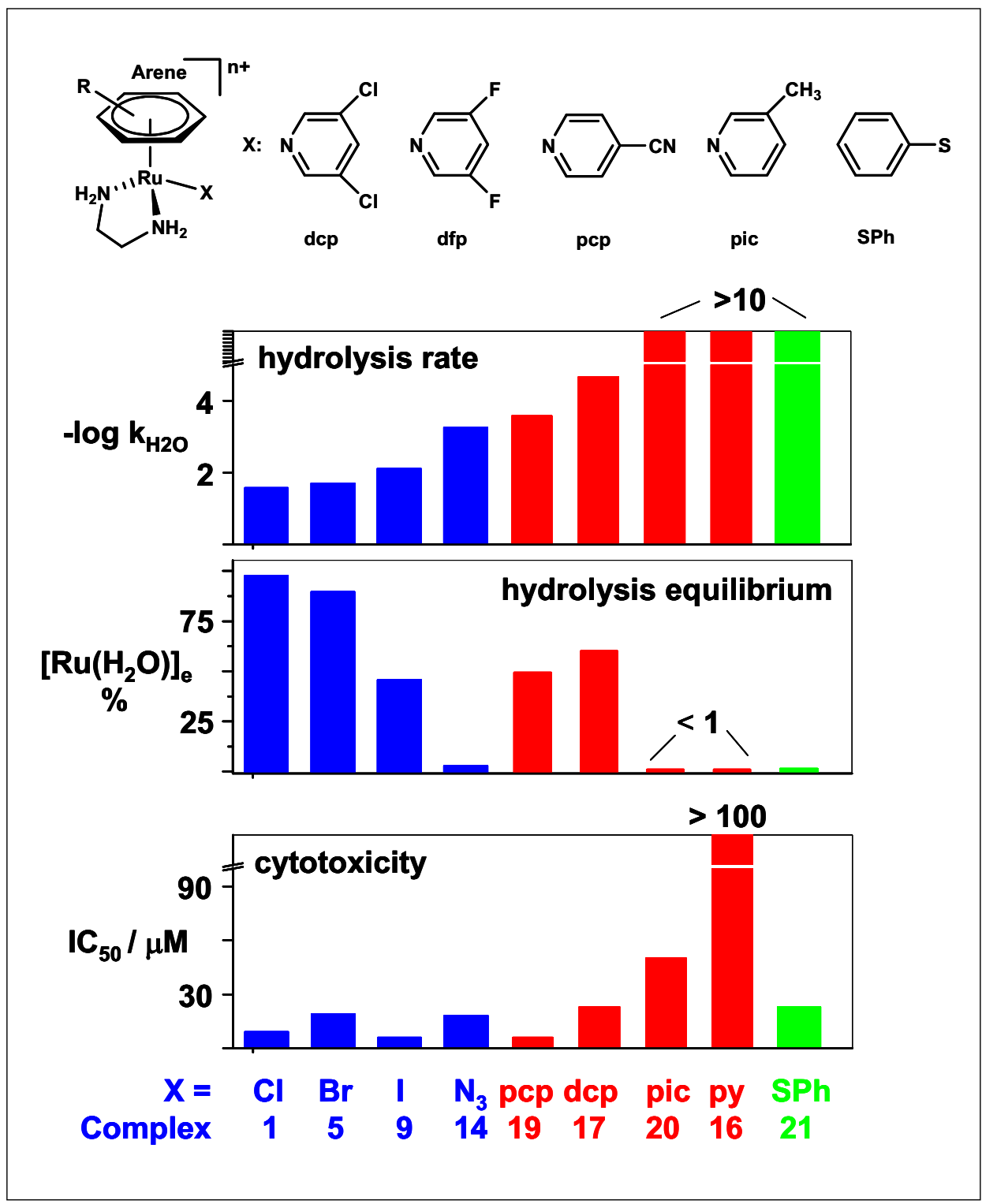

Fig. 2. Correlation of hydrolysis with cytotoxicity. (Upper) Structures of the complexes and leaving groups. (Lower) Hydrolysis rates, equilibrium percentage of total $\mathrm{Ru}$ as $\left[\left(\eta^{6}-\mathrm{hmb}\right) \mathrm{Ru}(\mathrm{en}) \mathrm{H}_{2} \mathrm{O}\right]^{2+}$ $\left(\left[\mathrm{Ru}\left(\mathrm{H}_{2} \mathrm{O}\right)\right]_{\mathrm{e}} \%\right)$ and $\mathrm{A} 2780$ cancer cell cytotoxicity $\mathrm{IC}_{50}$ values for $\left[\left(\eta^{6}-\mathrm{hmb}\right) \mathrm{Ru}(\mathrm{en}) \mathrm{X}\right]^{\mathrm{n}+}$ complexes with different 'leaving groups'. Adapted from ref. [20]. 
tensively, in both the solid (X-ray crystal though there is strong bonding between the DNA nucleobase and $\mathrm{Ru}^{\mathrm{II}}$, other non-covalent interactions including intercalation and hydrogen-bonding become important for DNA recognition.

\subsubsection{Arene-Nucleobase Stacking}

The X-ray crystal structures of $\left[\left(\eta^{6}-\right.\right.$ tha)Ru(en)9Et-G(N(7)) $]^{2+}$ and $\left[\left(\eta^{6}-\right.\right.$ dha $)$ $\mathrm{Ru}(\mathrm{en}) 9 \mathrm{Et}-\mathrm{G}(\mathrm{N}(7))]^{2+}$ show the presence of strong intramolecular $\pi-\pi$ arene-nucleobase stacking. The outer ring of tha/dha lies directly over the purine base and the centroid-centroid separation between the outer ring of the arene and the purine ring is $3.45 \AA$ for $\left[\left(\eta^{6}\right.\right.$-tha) $\mathrm{Ru}(\mathrm{en}) 9 \mathrm{Et}-\mathrm{G}(\mathrm{N}(7))]^{2+}$, and $3.31 \AA$ for $\left[\left(\eta^{6}-\right.\right.$ dha)Ru(en)9Et-G(N(7)) $]^{2+}$, with dihedral angles of $3.3^{\circ}$ and $3.1^{\circ}$ respectively. This strong stacking is essentially optimum; the outer arene ring is parallel to and fully overlaps the purine ring (see Fig. 3). Face to face $\pi-\pi$ stacking is reported to be optimized when both partners are electron poor ${ }^{[24]}$ and so the polarization of the arene and guanine ligands by $\mathrm{Ru}^{\mathrm{II}}$ may be an important factor for the stabilization for arene-nucleobase stacking. For the biphenyl complex [ $\left(\eta^{6}-\right.$ biphenyl)Ru(en)9Et-G(N(7)) $]^{2+}$, no instructures) and solution (NMR) state. ${ }^{[23]} \mathrm{Al}$ -

tramolecular stacking between the pendant phenyl ring and the nucleobase was observed due to the biphenyl adopting an anti conformation with respect to the purine base. Intermolecular stacking between the pendant phenyl ring and a purine base on an adjacent cation occurs with a centroid to centroid distance of $4.0 \AA$ and a dihedral angle of $4.5^{\circ}$. Thus the arene-nucleobase stacking in the biphenyl adduct is accompanied by a longer centroid-centroid distance and this is because of the higher degree of freedom for the movement of the biphenyl ring, i.e. the free propeller twisting of the phenyl ring in bip compared to the relatively rigid tricyclic frames of tha and dha.

In solution, ${ }^{1} \mathrm{H}$ 2D NOESY NMR experiments confirm that the pendant phenyl ring in complex $\left[\left(\eta^{6}\right.\right.$-biphenyl)Ru(en $) 9 \mathrm{Et}-$ $\mathrm{G}(\mathrm{N}(7))]^{2+}$ adopts a syn conformation with respect to the $\mathrm{G}$ base. [23]

\subsubsection{Specific Hydrogen Bonding}

In all three crystal structures of $\left[\left(\eta^{6}\right.\right.$ biphenyl)Ru(en)9Et-G(N(7)) $]^{2+}, \quad\left[\left(\eta^{6}-\right.\right.$ tha)Ru(en)9Et-G(N(7)) $]^{2+}$ and $\left[\left(\eta^{6}-\mathrm{dha}\right)\right.$ $\mathrm{Ru}(\mathrm{en}) 9 \mathrm{Et}-\mathrm{G}(\mathrm{N}(7))]^{2+}$, strong stereospecific hydrogen-bonding occurs between an en NH proton oriented away from the arene, pointing towards the DNA base (socalled $\mathrm{NH}_{\text {down }}$ protons) and the $\mathrm{C} 6$ carbonyl
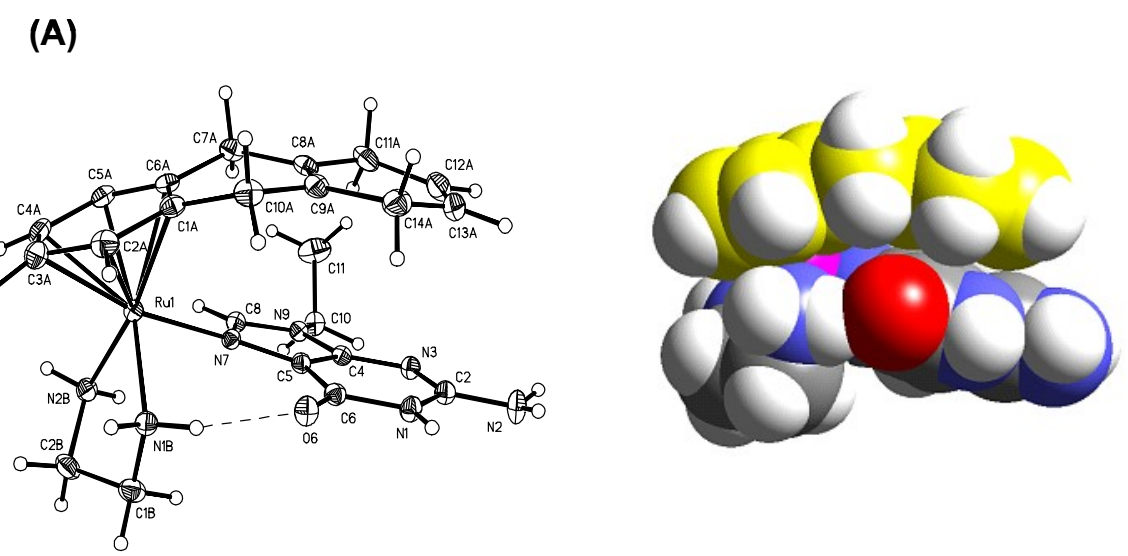

(B)
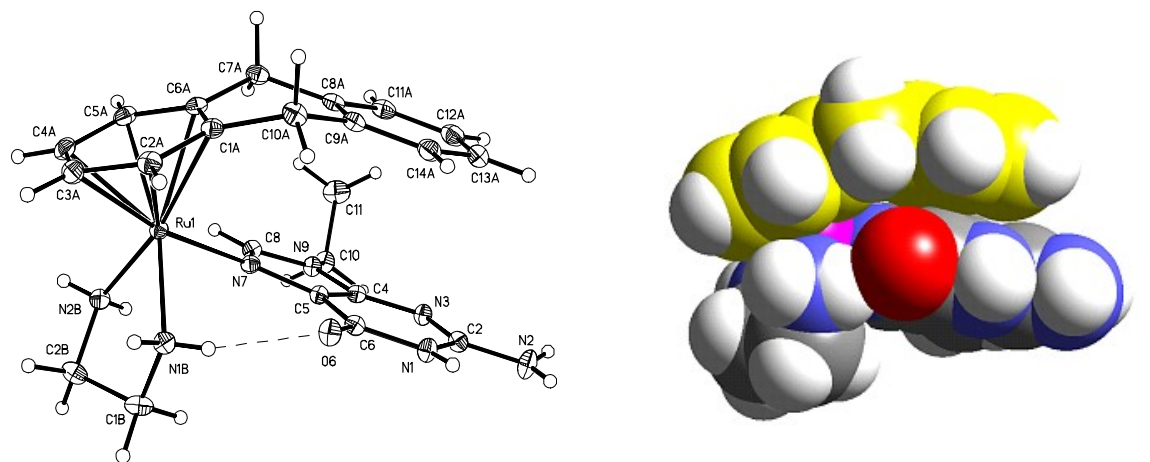

Fig. 3. X-ray structures (at 30\% probability thermal ellipsoids) and atom numbering schemes for (A) $\left[\left(\eta^{6}-\mathrm{C}_{14} \mathrm{H}_{14}\right) \mathrm{Ru}(\mathrm{en}) 9 \mathrm{EtG}-\mathrm{N}(7)\right]^{2+}$, and (B) $\left[\left(\eta^{6}-\mathrm{C}_{14} \mathrm{H}_{12}\right) \mathrm{Ru}(\mathrm{en}) 9 \mathrm{EtG}-\mathrm{N}(7)\right]^{2+}$. The space-filling models show the intramolecular arene-guanine base stacking and $\mathrm{H}$-bonding interactions between en $\mathrm{NH}$ and $\mathrm{G}$ O6. Colour code: $\mathrm{C}$ of $\mathrm{C}_{14} \mathrm{H}_{14}$ and $\mathrm{C}_{14} \mathrm{H}_{12}$ yellow, $\mathrm{C}$ of $9 \mathrm{EtG}$ and en gray, Ru purple, $\mathrm{O}$ red, $\mathrm{N}$ blue, and $\mathrm{H}$ white. Adapted from ref. [23]. oxygen of the guanine (average distances $\left.2.8 \AA \mathrm{N} \cdots \mathrm{O}, \mathrm{N}-\mathrm{H} \cdots \mathrm{O} 163^{\circ}\right) .{ }^{[23]}$ Such stereospecific hydrogen-bonding between the en ligand and the exocyclic oxygen atom of guanine, may play an important role in both the stability and conformation of this adduct.

\subsubsection{DNA Base Selectivity}

Ruthenium(II) en complexes bind preferentially to $\mathrm{N}(7)$ of guanine. ${ }^{[25]}$ Experiments have been preformed to determine the species produced after $24 \mathrm{~h}$ reaction of $\left[\left(\eta^{6} \text {-biphenyl }\right) \mathrm{Ru}(\mathrm{en}) \mathrm{Cl}\right]^{+}$with guanosine, inosine, thymidine, cytidine and adenosine. ${ }^{[25]}$ It was shown that the complex has a high selectivity for guanosine with $100 \%$ reaction to form the guanosine adduct. A significant percentage of complex binds to the $N(7)$ and $N(1)$ of inosine (82\%) and a small percentage forms a dinuclear species in which one ruthenium binds to $\mathrm{N}(3)$ and another to $\mathrm{N}(1)$ (accounting for $c a .4 \%$ of the Ru). Significant binding (ca. 31\%) was also observed to $\mathrm{N}(3)$ of thymidine, but contrastingly only a small percentage binds to $\mathrm{N}(3)$ of cytidine (12\%), and even less $(<3 \%)$ to adenosine. Thus the overall order of base selectivity is $\mathrm{G}(\mathrm{N}(7))>$ $\mathrm{I}(\mathrm{N}(7))>\mathrm{I}(\mathrm{N}(1)), \mathrm{T}(\mathrm{N}(3))>\mathrm{C}(\mathrm{N}(3))$ $>\mathrm{A}(\mathrm{N}(7))$, A $(\mathrm{N}(1))>\mathrm{G}(\mathrm{N}(1))$. The observed base selectivity can be rationalized in terms of hydrogen bonding attractions/ repulsions. Thus coordination at the $\mathrm{N}(7)$ of guanine is stabilized by the hydrogen bonding of en $\mathrm{N}-\mathrm{H}$ with guanosine $\mathrm{C}(6)-\mathrm{O}$. Coordination at $\mathrm{N}(1)$ of $\mathrm{G}$ is unfavourable due to the potentially repulsive interaction between the en $\mathrm{NH}_{2}$ and guanine $\mathrm{C} 2 \mathrm{NH}_{2}$ groups. Because inosine has no $\mathrm{NH}$ groups, coordination at either $\mathrm{N}(7)$ or $\mathrm{N}(1)$ can be stabilized by hydrogen-bonding of inosine $\mathrm{C}(6)-\mathrm{O}$ resulting in significant amounts of both species being formed. For thymidine, coordination at $\mathrm{N}(3)$ may be favoured by hydrogen-bonds between en $\mathrm{NH}$ and the exocyclic oxygen's at $\mathrm{C} 2$ and $\mathrm{C} 4$, whereas for cytidine, only a small reaction by coordination at $\mathrm{N}(3)$ is observed. Coordination is thought to be weak partly due to a repulsive interaction of en $\mathrm{NH}$ with the $\mathrm{C} 4 \mathrm{NH}_{2}$ group. For adenosine any coordination at the $\mathrm{N}(7)$ or $\mathrm{N}(1)$ is weakened by repulsive interactions with the exocyclic amino group and as a result negligible binding is observed. For reactions with mononucleotides, a similar pattern of selectivity is observed, except that significant amounts of $5^{\prime}$ phosphate bound species $(40-60 \%)$ are present at equilibrium for $5^{\prime}$-TMP, 5'-CMP and 5'-AMP (but not 5'-GMP, cGMP or c-AMP).

In competitive reactions between $\left[\left(\eta^{6}\right.\right.$ biphenyl) $\mathrm{Ru}(\mathrm{en}) \mathrm{Cl}]^{+}$and the cyclic nucleotide diesters c-GMP versus c-TMP, cCMP or c-AMP monitored over $48 \mathrm{~h}(5 \mathrm{mM}$ $\mathrm{Ru}, 1: 1$ nucleotides, $\mathrm{pH} 7.2,310 \mathrm{~K}$ ) only 
Table. Half lives $\left(t_{1 / 2}\right)$ for reactions of $\mathrm{Ru}^{\prime \prime}$ arene complexes $\left[\left(\eta^{6}\right.\right.$-arene)Ru(en)Cl] ${ }^{+}$and the corresponding aqua complexes $\left[\left(\eta^{6} \text {-arene) } \mathrm{Ru}(\mathrm{en}) \mathrm{OH}_{2}\right]^{2+}\right.$ with cGMPa .

\begin{tabular}{|c|c|c|c|}
\hline$\left[\left(\eta^{6} \text {-arene }\right) \mathrm{Ru}(\mathrm{en}) \mathrm{Cl}\right]^{+}$ & $t_{(1 / 2)}[h]$ & {$\left[\left(\eta^{6} \text {-arene }\right) \mathrm{Ru}(\mathrm{en}) \mathrm{OH}_{2}\right]^{2+}$} & $\mathrm{t}_{(1 / 2)}[\mathrm{h}]$ \\
\hline tha & 1.1 & tha & 0.38 \\
\hline bip & 2.0 & bip & 0.69 \\
\hline dha & 3.6 & dha & 0.78 \\
\hline$p$-cym & 7.1 & $p$-cym & 2.23 \\
\hline $\mathrm{bz}$ & 13 & $\mathrm{bz}$ & 4.94 \\
\hline
\end{tabular}

Ru-c-GMP adduct is formed confirming the preferential binding to c-GMP. ${ }^{[25]}$

\subsubsection{Rates of Reactions with cGMP}

The half-lives for reaction of five ruthenium(II) arene en chloride complexes (arene $=$ bip, tha, dha, bz and $p$-cym; bz = benzene, $p$-cym $=p$-cymene) and the corresponding aqua adducts with c-GMP are summarized in the Table. ${ }^{[25]}$ The rates of reaction of c-GMP with $\left[\left(\eta^{6}\right.\right.$-tha) Ru(en) $\left.\mathrm{OH}_{2}\right]^{2+},\left[\left(\eta^{6}-\mathrm{dha}\right) \mathrm{Ru}(\mathrm{en}) \mathrm{OH}_{2}\right]^{2+}$ and $\left[\left(\eta^{6}-\right.\right.$ bip) $\left.\mathrm{Ru}(\mathrm{en}) \mathrm{OH}_{2}\right]^{2+}$ complexes are more than three times faster than those for the $\left[\left(\eta^{6}-\right.\right.$ $p$-cym $\left.) \mathrm{Ru}(\mathrm{en}) \mathrm{OH}_{2}\right]^{2+}$ and $\left[\left(\eta^{6}\right.\right.$-bz) Ru(en) $\left.\mathrm{OH}_{2}\right]^{2+}$ complexes. The rates of reaction of the chloride complexes are slower due to the two-step process of reaction: hydrolysis followed by $\mathrm{Ru}-\mathrm{N}(7)$ binding. The same trend in reactivity was observed for the chlorido and aqua complexes. For the complexes $\left[\left(\eta^{6} \text {-tha }\right) \mathrm{Ru}(\mathrm{en}) \mathrm{Cl}\right]^{+},\left[\left(\eta^{6}\right.\right.$-dha $)$ $\mathrm{Ru}(\mathrm{en}) \mathrm{Cl}]^{+}$and $\left[\left(\eta^{6} \text {-bip) } \mathrm{Ru}(\mathrm{en}) \mathrm{Cl}\right]^{+}, 100 \%\right.$ of the N(7)-bound product was observed after $2 \mathrm{~d}$ whereas only $c a .80 \%$ of the N(7) bound product formed for the $p$-cym and bz complexes after $4 \mathrm{~d}$. Thus the rate of reaction of the $\mathrm{Ru}$ aqua complexes (and chloro complexes) with c-GMP depends markedly on the nature of the arene decreasing by over an order of magnitude as the arene is changed from tha $>$ bip $>$ dha $>>$-cym $>$ bz. Because the fastest rates are for the complexes containing the larger arene ligands, this implies lower activation energies $\left(\Delta \mathrm{G}^{\ddagger}\right)$ for formation of seven-coordinate transition states (assuming an associative mechanism). A significant contribution to $\Delta \mathrm{G}^{\ddagger}$ may arise from $\pi-\pi$ stacking of the arene and the purine ring in the transition state (negative $\Delta \mathrm{H}^{\ddagger}$ ). Such an interaction is not possible for the $p$-cymene and benzene complexes. Thus these hydrophobic interactions could produce an additional driving force for DNA binding.

\subsubsection{Interactions with Oligonucleotides}

Studies on the interaction of [( $\eta^{6}$-bip $)$ $\mathrm{Ru}(\mathrm{en}) \mathrm{Cl}]^{+}$with single strand DNA 14-mer
d(ATACATGGTACATA) (I) or its complementary strand d(TATGTACCATGTAT) (II) gave either mono- or di-ruthenated species (binding at $\mathrm{G}$ ) depending on the ratio of Ru:single strand.[26] Interestingly, the annealation of mono-ruthenated (II) with strand (I) (heat to $353 \mathrm{~K}$ for $2 \mathrm{~min}$ followed by slow cooling to $288 \mathrm{~K}$ over $3 \mathrm{~h}$ ) gave a product in which all four $G$ bases were ruthenated. Thus $\left[\left(\eta^{6} \text {-bip }\right) \mathrm{Ru}(\mathrm{en}) \mathrm{Cl}\right]^{+}$is highly specific for $\mathrm{G}(\mathrm{N}(7))$ but is mobile at elevated temperatures at which migration between guanine residues is facile. This behaviour suggests that organometallic ruthenium(II) arene complexes can be readily removed from DNA, which may be beneficial for reversing DNA damage in cells. Furthermore the dynamic behaviour of arene intercalation of the pendant phenyl ring in the biphenyl arene was demonstrated (in solution by ${ }^{1} \mathrm{H}$ NMR) where equilibria exist between intercalated and non-intercalated forms. ${ }^{[26]}$

The interaction of $\left[\left(\eta^{6} \text {-bip }\right) \mathrm{Ru}(\mathrm{en}) \mathrm{Cl}\right]^{+}$ with the duplex d(CGGCCG) ${ }_{2}$ revealed that there was preferential binding at G3 and G6 with no binding observed at $\mathrm{G} 2$, attributable to unfavourable steric interactions between the duplex and the arene. ${ }^{[27]}$ So not only is sequence specificity important in the recognition process, site specificity also can play an important role.

\subsubsection{Reactions with DNA}

The interaction of several ruthenium arene complexes with DNA in a cell-free medium has been studied using several different techniques. ${ }^{[28]}$ The extent of ruthenation of double helical CT-DNA $(0.1 \mathrm{mg} / \mathrm{ml})$ by the arene complexes at an $r_{i}$ value of 0.1 (molar ratio of free ruthenium complex to nucleotide phosphates at the onset of incubation with DNA) in $10 \mathrm{mM} \mathrm{NaClO}_{4}$ at 310 $\mathrm{K}$ was followed. The amount of ruthenium bound per DNA nucleotide phosphate increases with time and the time at which binding reaches $50 \%\left(\mathrm{t}_{50 \%}\right)$ is markedly dependent on the arene: $10 \mathrm{~min}\left(\left[\left(\eta^{6}-\right.\right.\right.$ bip $)$ $\left.\mathrm{Ru}(\mathrm{en}) \mathrm{Cl}]^{+}\right)$and $\left(\left[\left(\eta^{6} \text {-tha }\right) \mathrm{Ru}(\mathrm{en}) \mathrm{Cl}\right]^{+}\right), 15$ $\min \left(\left[\left(\eta^{6}-\mathrm{dha}\right) \mathrm{Ru}(\mathrm{en}) \mathrm{Cl}\right]^{+}\right)$and $3.5 \mathrm{~h}\left(\left[\left(\eta^{6}\right.\right.\right.$ $p$-cym $\left.) \mathrm{Ru}(\mathrm{en}) \mathrm{Cl}]^{+}\right)$. Under the same conditions $\mathrm{t}_{50 \%}$ for cisplatin binding is $c a .2$ h. Thus for $\left[\left(\eta^{6} \text {-bip) } \mathrm{Ru}(\mathrm{en}) \mathrm{Cl}\right]^{+},\left[\left(\eta^{6}\right.\right.\right.$-tha) $\mathrm{Ru}(\mathrm{en}) \mathrm{Cl}]^{+}$and $\left[\left(\eta^{6} \text {-dha }\right) \mathrm{Ru}(\mathrm{en}) \mathrm{Cl}\right]^{+}$, reactions are an order of magnitude faster than for cisplatin. The binding was also nearly quantitative - for $\left[\left(\eta^{6} \text {-bip }\right) \mathrm{Ru}(\mathrm{en}) \mathrm{Cl}\right]^{+}$after $c a .3 \mathrm{~h} c a .90 \%$ of the ruthenium was bound to DNA. Transcription mapping experiments have shown that the ruthenium complexes bind mainly at guanine sites on DNA. ${ }^{[28]}$

\subsubsection{RNA Synthesis}

The in vitro RNA synthesis by RNA polymerases on DNA templates was studied using a linear DNA fragment modified by these ruthenium arene complexes, cisplatin and monofunctional [Pt(dien) Cl]Cl. ${ }^{[28]}$ RNA synthesis on these modified plasmid fragments yielded fragments of defined size, which indicates that RNA synthesis on these templates was prematurely terminated (for Ru complexes mainly at guanine residues). For cisplatin the termination sites are similar as for the $\mathrm{Ru}(\mathrm{II})$ arenes (i.e. mainly at $\mathrm{G}$ ) but the efficiency of the ruthenium-adducts to terminate RNA synthesis in vitro is reduced relative to that of cisplatin. Furthermore the efficiency of the $\left[\left(\eta^{6}-p \text {-cym }\right) \mathrm{Ru}(\mathrm{en}) \mathrm{Cl}\right]^{+}$adducts was noticeably lower than for the other three $\mathrm{Ru}^{\mathrm{II}}$ arenes. Interestingly, no termination of RNA synthesis by the monofunctional [Pt(dien) $\mathrm{Cl}] \mathrm{Cl}$ was observed, and this inability has been observed for several monofunctional platinum adducts. ${ }^{[29-31]}$ This suggests that the ruthenium complexes bind and distort DNA in a somewhat different fashion to the mononuclear $\mathrm{Pt}$ complex $[\mathrm{Pt}(\operatorname{dien}) \mathrm{Cl}] \mathrm{Cl}$.

\subsubsection{Circular Dichroism}

The binding of ruthenium arene compounds $\quad\left[\left(\eta^{6} \text {-bip }\right) \mathrm{Ru}(\mathrm{en}) \mathrm{Cl}\right]^{+}, \quad\left[\left(\eta^{6}\right.\right.$-tha $)$ $\mathrm{Ru}(\mathrm{en}) \mathrm{Cl}]^{+},\left[\left(\eta^{6}-\mathrm{dha}\right) \mathrm{Ru}(\mathrm{en}) \mathrm{Cl}\right]^{+}, \quad\left[\left(\eta^{6}-p-\right.\right.$ cym $) \mathrm{Ru}(\mathrm{en}) \mathrm{Cl}]^{+}$, and $\left[\left(\eta^{6}-\mathrm{bz}\right) \mathrm{Ru}(\mathrm{en}) \mathrm{Cl}\right]^{+}$ to CT DNA and double-stranded polynucleotide complexes poly (dG-dC) and poly (dA-dT) has been studied by circular dichroism (CD). ${ }^{[28]}$ An induced $C D$ band at $350-410 \mathrm{~nm}$ was observed for the interaction of $\left[\left(\eta^{6} \text {-bip }\right) \mathrm{Ru}(\mathrm{en}) \mathrm{Cl}\right]^{+},\left[\left(\eta^{6}\right.\right.$-tha $)$ $\mathrm{Ru}(\mathrm{en}) \mathrm{Cl}]^{+}$and $\left[\left(\eta^{6}-\mathrm{dha}\right) \mathrm{Ru}(\mathrm{en}) \mathrm{Cl}\right]^{+}$, with both CT-DNA and poly (dG-dC) whereas no induced band in this near UV region was observed for $\left[\left(\eta^{6}-p \text {-cym }\right) \mathrm{Ru}(\mathrm{en}) \mathrm{Cl}\right]^{+}$, or $\left[\left(\eta^{6}-\mathrm{bz}\right) \mathrm{Ru}(\mathrm{en}) \mathrm{Cl}\right]^{+}$. This induced $\mathrm{CD}$ band appears to be related to intercalation of the extended arene ligands into DNA or to groove binding. The observation of such bands has been well documented for intercalation of other metal complexes. ${ }^{[32,33]}$ For poly (dA-dT), only the complexes with extended $\pi$-systems $\left(\left[\left(\eta^{6} \text {-bip }\right) \mathrm{Ru}(\mathrm{en}) \mathrm{Cl}\right]^{+}\right.$, $\left[\left(\eta^{6} \text {-tha }\right) \mathrm{Ru}(\mathrm{en}) \mathrm{Cl}\right]^{+}$and $\left[\left(\eta^{6}\right.\right.$-dha $) \mathrm{Ru}(\mathrm{en})$ $\left.\mathrm{Cl}]^{+}\right)$induced any spectral changes and these were small, confined to the region 260-280 
$\mathrm{nm}$ and were ascribed to weak hydrophobic interactions between the arene and the DNA base. Because only a weak binding to $\mathrm{A}$ or $\mathrm{T}$ bases is expected (vide supra) this accounts for the differences between poly (dA-dT) and poly (dG-dC) spectra.

\subsubsection{Linear Flow Dichroism}

Linear flow dichroism studies showed that ruthenation of CT DNA and poly $(\mathrm{dG}-$ $\mathrm{dC}$ ) causes bending of the DNA. The three possible intercalating complexes ([( $\eta^{6}$-bip) $\mathrm{Ru}(\mathrm{en}) \mathrm{Cl}]^{+},\left[\left(\eta^{6} \text {-tha) } \mathrm{Ru}(\mathrm{en}) \mathrm{Cl}\right]^{+},\left[\left(\eta^{6}\right.\right.\right.$-dha $)$ $\mathrm{Ru}(\mathrm{en}) \mathrm{Cl}]^{+}$) cause a wavelength shift consistent with intercalation of the arene ligands but the bending precludes full intercalation. $\left[\left(\eta^{6}-p \text {-cym }\right) \mathrm{Ru}(\mathrm{en}) \mathrm{Cl}\right]^{+}$and $\left[\left(\eta^{6}-\mathrm{bz}\right) \mathrm{Ru}(\mathrm{en})\right.$ $\mathrm{Cl}]^{+}$were found to rigidify poly (dA-dT) DNA, whereas the intercalating complexes cause significant bending, with $\left[\left(\eta^{6}-\mathrm{dha}\right)\right.$ $\mathrm{Ru}(\mathrm{en}) \mathrm{Cl}]^{+}$inducing the most bending. The LD observed for the binding to poly (dA$\mathrm{dT}$ ) is consistent with a mode involving the aromatic ligands inserted into the minor groove.

\subsubsection{Ethidium Bromide \\ Experiments}

The intercalation of the arene ligands into double helical DNA has been confirmed by ethidium bromide (EtBr) fluorescence experiments. ${ }^{[28]} \mathrm{EtBr}$ is a probe which is fluorescent when bound to DNA and can be used to distinguish intercalating and nonintercalating ligands on DNA by competition. ${ }^{[34]}$ Complexes $\left[\left(\eta^{6} \text {-bip }\right) \mathrm{Ru}(\mathrm{en}) \mathrm{Cl}\right]^{+}$, $\left[\left(\eta^{6} \text {-tha }\right) \mathrm{Ru}(\mathrm{en}) \mathrm{Cl}\right]^{+}$and $\left[\left(\eta^{6}\right.\right.$-dha $) \mathrm{Ru}(\mathrm{en})$ $\mathrm{Cl}]^{+}$can intercalate into the double helix of DNA, whereas $\left[\left(\eta^{6}-p \text {-cym }\right) \mathrm{Ru}(\mathrm{en}) \mathrm{Cl}\right]^{+}$ does not.

\subsubsection{DNA Unwinding}

Complexes [( $\eta^{6}$-bip)Ru(en)Cl] $]^{+},\left[\left(\eta^{6}-\right.\right.$ tha) $\mathrm{Ru}(\mathrm{en}) \mathrm{Cl}]^{+}$and $\left[\left(\eta^{6}-\mathrm{dha}\right) \mathrm{Ru}(\mathrm{en}) \mathrm{Cl}\right]^{+}$ unwind negatively supercoiled pSP73KB plasmid DNA by $14 \pm 1^{\circ}$ per bound ruthenium and $\left[\left(\eta^{6}-p-c y m\right) \mathrm{Ru}(\mathrm{en}) \mathrm{Cl}\right]^{+}$by only $7 \pm 0.5^{\circ} .{ }^{[28]}$ These results suggest that the extra unwinding is a result of the intercalation of the extended arene or another noncovalent interaction of these complexes with DNA upon mono-functional binding. Large unwinding angles of 15 or $19^{\circ}$ produced for the platinum compounds cis$\left[\mathrm{Pt}-\left(\mathrm{NH}_{3}\right)_{2}(\mathrm{~N} 8-\mathrm{ethidium}) \mathrm{Cl}\right]^{2+}$ and cis-[Pt$\left(\mathrm{NH}_{3}\right)_{2}(\mathrm{~N}(3)$-ethidium $\left.) \mathrm{Cl}\right]^{2+}$ which contain the known intercalator ethidium and can form only mono-functional adducts with DNA, have also been explained this way. ${ }^{[35]}$

\subsubsection{DNA Melting Temperature $\left(t_{m}\right)$}

At lower salt concentrations $(0.01 \mathrm{M}$ $\left.\mathrm{NaClO}_{4}\right), \quad\left[\left(\eta^{6} \text {-bip }\right) \mathrm{Ru}(\mathrm{en}) \mathrm{Cl}\right]^{+}, \quad\left[\left(\eta^{6}\right.\right.$-tha $)$ $\mathrm{Ru}(\mathrm{en}) \mathrm{Cl}]^{+}$and $\left[\left(\eta^{6} \text {-dha }\right) \mathrm{Ru}(\mathrm{en}) \mathrm{Cl}\right]^{+}$increase the melting temperature $\left(\mathrm{t}_{\mathrm{m}}\right)$ of calf thymus (CT)-DNA. The increase becomes more pronounced with increasing $r_{b}$ val- ues, where $r_{b}=$ number of Ru atoms bound per nucleotide. As the ionic strength is increased, the enhancement of $t_{m}\left(\Delta t_{m}\right)$ due to the presence of the ruthenium compounds decreased and at higher salt concentrations $(0.2 \mathrm{M}) \mathrm{t}_{\mathrm{m}}$ decreased. The dependence of $\mathrm{t}_{\mathrm{m}}$ of DNA modified by ruthenium at differing ionic strengths is due to competing electrostatic effects as the salt concentration is varied. ${ }^{[36]}$ At low ionic strengths the increase in $t_{m}$ due to the modification of DNA by $\left[\left(\eta^{6} \text {-bip }\right) \mathrm{Ru}(\mathrm{en}) \mathrm{Cl}\right]^{+}, \quad\left[\left(\eta^{6} \text {-tha }\right) \mathrm{Ru}(\mathrm{en}) \mathrm{Cl}\right]^{+}$ and $\left[\left(\eta^{6}-\mathrm{dha}\right) \mathrm{Ru}(\mathrm{en}) \mathrm{Cl}\right]^{+}$are caused by the positive charges on the ruthenium and by the intercalation.

Three factors appear to account for the change in thermal stability of DNA modified by ruthenium:

i) stabilizing effects of the positive charge on the ruthenium fragments,

ii) stabilizing effects of DNA interstrand crosslinks, and

iii) destabilizing effects of conformational distortions such as intrastrand crosslinks induced in DNA by ruthenium coordination.

A further two additional factors may be involved in DNA stabilization by intercalators; favourable stacking interactions between the base residues and the intercalator and the separation of negative backbone charges inherent to intercalation (due to elongation and unwinding of DNA).

Contrastingly, the melting behaviour of DNA modified by $\left[\left(\eta^{6}-p\right.\right.$-cym $) \mathrm{Ru}(\mathrm{en})$ $\mathrm{Cl}]^{+}$, results in a similar decrease in $\mathrm{t}_{\mathrm{m}}$ at all ionic strengths. ${ }^{[28]}$ It is not known as yet why the modification at higher salt concentrations appears to result in a smaller thermal stabilization or even destabilization, although some possibilities have been suggested. ${ }^{[28]}$ The melting behaviour of $\left[\left(\eta^{6}-p \text {-cym }\right) \mathrm{Ru}(\mathrm{en}) \mathrm{Cl}\right]^{+}$decreases $\mathrm{t}_{\mathrm{m}}$ even at a lower salt concentration, indicating that the factors responsible for thermal stabilization of DNA are notably reduced. Thus it is likely that the stabilizing effects of the positive charge on the ruthenium atom are markedly reduced so that the destabilization effect of conformational alterations induced by $\left[\left(\eta^{6}-p\right.\right.$-cym $) \mathrm{Ru}(\mathrm{en})$ $\mathrm{Cl}]^{+}$predominates already at low salt concentrations.

\subsubsection{Differential Pulse \\ Polarography}

CT-DNA modified by ruthenium complexes was analyzed by differential pulse polarography (DPP). ${ }^{[28]}$ Intact double helical DNA is polarographically inactive because its reduction sites are involved in hydrogen bonds and thus cannot be electrochemically reduced. However, electroreduction of adenosine or cytosine residues present on distorted but still double stranded (nondenatured) DNA generates a small DPP peak (peak I). The appearance of more negative peaks in the DPP curves indicates the presence of single stranded denatured regions in the DNA molecule in which hydrogen bonds between complementary bases have been broken and so are readily electrochemically reduced (peak II). Results show that $\left[\left(\eta^{6}\right.\right.$-bip) $\mathrm{Ru}(\mathrm{en}) \mathrm{Cl}]^{+},\left[\left(\eta^{6} \text {-tha }\right) \mathrm{Ru}(\mathrm{en}) \mathrm{Cl}\right]^{+}$and $\left[\left(\eta^{6}{ }_{-}\right.\right.$ dha) $\mathrm{Ru}(\mathrm{en}) \mathrm{Cl}]^{+}$induce non-denaturational conformational distortions of CT-DNA at low levels of global modification $\left(r_{b}\right.$ values of $0.0005-0.01$ ) with an increase in intensity of peak I with increasing values of the modification. This behaviour is similar to that observed for cisplatin and its analogues. ${ }^{[37,38]}$ In contrast, for $\mathrm{Ru}$ $p$-cym an increase in intensity of peak I was observed at low concentrations of the DNA modification $\left(r_{b} \leq 0.005\right)$ and higher levels of DNA modification peak II were observed. This supports the view that the DNA binding mode of the $\left[\left(\eta^{6}-p\right.\right.$-cym $)$ $\mathrm{Ru}(\mathrm{en}) \mathrm{Cl}]^{+}$is different from that of the $\left[\left(\eta^{6} \text {-bip }\right) \mathrm{Ru}(\text { en }) \mathrm{Cl}\right]^{+}, \quad\left[\left(\eta^{6} \text {-tha }\right) \mathrm{Ru}(\mathrm{en}) \mathrm{Cl}\right]^{+}$ and $\left[\left(\eta^{6}-\mathrm{dha}\right) \mathrm{Ru}(\mathrm{en}) \mathrm{Cl}\right]^{+}$analogues and that modification of DNA by $\left[\left(\eta^{6}-p\right.\right.$-cym $)$ $\mathrm{Ru}(\mathrm{en}) \mathrm{Cl}]^{+}$may even lead to denaturational distortions of DNA.

\subsubsection{Isothermal Titration Calorimetry}

The conformation of DNA modified by the ruthenium arene complexes $\left[\left(\eta^{6}\right.\right.$-tha) $\mathrm{Ru}(\mathrm{en}) \mathrm{Cl}]^{+}$and $\left[\left(\eta^{6}-p \text {-cym }\right) \mathrm{Ru}(\mathrm{en}) \mathrm{Cl}\right]^{+}$has been further studied by isothermal titration calorimetry (ITC). ${ }^{[39]}$ Data show that ruthenation of the duplex 5'-CTCTCTTGTCTTCTC-3' is exothermic and results in a large decrease in enthalpy of duplex formation by 4.4 and $7.4 \mathrm{kcal} \mathrm{mol}^{-1}$ for the tha and $p$-cym complexes, respectively, and in a substantial decrease in the entropy of the duplex of 11.6 or $18.2 \mathrm{cal} \mathrm{K}^{-1} \mathrm{~mol}^{-1}$ (T $\Delta \Delta \mathrm{S} 3.6$ and $5.4 \mathrm{kcal} \mathrm{mol}^{-1}$ ), respectively. Thus we have enthalpic destabilization of the duplex relative to its non-modified analogue, but entropic stabilization of the duplex. The net result is that the formation of these mono-functional adducts with the duplex induces a decrease in duplex thermodynamic stability of 0.8 or $2.0 \mathrm{kcal}$ $\mathrm{mol}^{-1}$, with this destabilization being enthalpic in origin. The $\left[\left(\eta^{6}-p\right.\right.$-cym $) \mathrm{Ru}(\mathrm{en})$ $\mathrm{Cl}]^{+}$adduct was more destabilized than that of $\left[\left(\eta^{6} \text {-tha }\right) \mathrm{Ru}(\mathrm{en}) \mathrm{Cl}\right]^{+}$. The higher thermodynamic stability of the DNA adducts of $\left[\left(\eta^{6} \text {-tha }\right) \mathrm{Ru}(\mathrm{en}) \mathrm{Cl}\right]^{+}$may be associated with intercalation since various intercalators have been known to thermodynamically stabilize DNA. ${ }^{[40,41]}$

\subsubsection{DNA Repair Synthesis}

Considerably different levels of damage-induced DNA repair synthesis were detected in plasmids modified by $\left[\left(\eta^{6}-\right.\right.$ tha $)$ $\mathrm{Ru}(\mathrm{en}) \mathrm{Cl}]^{+}, \quad\left[\left(\eta^{6}-p \text {-cym }\right) \mathrm{Ru}(\mathrm{en}) \mathrm{Cl}\right]^{+}$and cisplatin. ${ }^{[39]}$ The level of synthesis detected 
in the plasmid modified by $\left[\left(\eta^{6}\right.\right.$-tha $) \mathrm{Ru}(\mathrm{en})$ $\mathrm{Cl}]^{+}$is $c a .6$ times lower than in that in the plasmid modified by $\left[\left(\eta^{6}-p-c y m\right) \operatorname{Ru}(e n)\right.$ $\mathrm{Cl}]^{+}$. DNA repair synthesis can occur by various repair mechanisms including cisplatin, are the nucleotide excision repair (NER) mechanism (the usual mechanism for cisplatin). Compared to cisplatin, the monofunctional adducts of [ $\left(\eta^{6}\right.$-tha $) \mathrm{Ru}(\mathrm{en})$ $\mathrm{Cl}]^{+}$and $\left[\left(\eta^{6}-p \text {-cym }\right) \mathrm{Ru}(\mathrm{en}) \mathrm{Cl}\right]^{+}$are excised with a significantly lower efficiency than the major intrastrand crosslink of cisplatin, and $\left[\left(\eta^{6}-p \text {-cym }\right) \mathrm{Ru}(\mathrm{en}) \mathrm{Cl}\right]^{+}$adducts are excised slightly more than those of $\left[\left(\eta^{6}-\right.\right.$ tha) $\mathrm{Ru}(\mathrm{en}) \mathrm{Cl}]^{+}$. The HMG (High Mobility Group) protein plays a role in sensitizing the cells to cisplatin. For example it has been shown that the HMG domain proteins recognize and bind to DNA adducts formed by cisplatin. ${ }^{[42]}$ An important structural motif recognized by HMG domain proteins on DNA modified by cisplatin is a directional bend of the helix axis towards the major groove. No recognition of the DNA monofunctional adducts of $\left[\left(\eta^{6} \text {-tha }\right) \mathrm{Ru}(\mathrm{en}) \mathrm{Cl}\right]^{+}$ or $\left[\left(\eta^{6}-p-c y m\right) \mathrm{Ru}(\mathrm{en}) \mathrm{Cl}\right]^{+}$by HMGB1 has been observed, suggesting that these adducts do not afford structural motifs recognized by HMG domain proteins. Thus the mechanism of antitumour activity of $\mathrm{Ru}^{\mathrm{II}}$ arenes does not involve recognition of its DNA adducts by HMG domain proteins as a crucial step, in direct contrast to cisplatin.

\subsubsection{Mechanism of Action}

\subsubsection{A2780 and 2780AD Cellular Resistance}

A high degree of cross resistance has been observed between $\mathrm{Ru}^{\mathrm{II}}$ arene complexes and adriamycin, as observed in the 2780AD cell line.[17] This cell line displays the classic Multi Drug Resistance (MDR) phenotype via over-expression of the 170 kD plasma membrane glycoprotein P-gp and reduced cellular drug accumulation. ${ }^{[43,44]}$ P-gp has a substrate specificity for naturally-occurring hydrophobic molecules, particularly those carrying a positive charge and so the cationic hydrophobic $\mathrm{Ru}^{\mathrm{II}}$ arene complexes exhibit both these features. Thus it is likely that the cross resistance to $\mathrm{Ru}^{\mathrm{II}}$ arene complexes is due, at least partly, to their recognition and active efflux by P-gp. This has been confirmed by co-administering verapamil (a drug known to abrogate effectively P-gp mediated active efflux by competitive inhibition of drug transport and hence reverse MDR) with the ruthenium complex $\left[\left(\eta^{6} \text {-bip) } \mathrm{Ru}(\mathrm{en}) \mathrm{Cl}\right]^{+}\right.$when the fold resistance decreased from 38-fold to three-fold, i.e. almost a complete reversal of drug resistance.

In contrast $\mathrm{Ru}^{\mathrm{II}}$ arene complexes are completely non-cross resistant towards the A2780cis cell line. This is interesting as it suggests that the mechanism of action differs from that of cisplatin.
In vivo antitumour activity in human ovarian A2780, 2780AD and A2780cis xenografts for the complex [( $\eta^{6}$-bip $) \mathrm{Ru}(\mathrm{en})$ $\mathrm{Cl}]^{+}$showed that it produced a significant growth delay in A2780 cells, maintained the growth inhibitory activity in the A2780cis xenograft, but was inactive against A2780AD cells. ${ }^{[17]}$ Thus, encouragingly, the patterns established in vitro were mirrored to a large degree in vivo.

\subsubsection{Downstream Effects}

The downstream mechanism of action of $\left[\left(\eta^{6} \text {-bip) } \mathrm{Ru}(\mathrm{en}) \mathrm{Cl}\right]^{+}\right.$in (un)derivatised HCT116 colon cells has been investigat$\mathrm{ed}^{[45]}$ since prediction or enhancement of tumoricidal effect, based on knowledge of cellular response determinants could improve the clinical utility of these types of complexes. HCT116-p53 null cells were two-fold more resistant than HCT116WT $(\mathrm{WT}=$ wild-type $)$ cells to short-time $\left[\left(\eta^{6} \text {-bip }\right) \mathrm{Ru}(\mathrm{en}) \mathrm{Cl}\right]^{+}$mediated growth suppression $\left(\mathrm{IC}_{50}\right.$ HCT116-WT $8 \mu \mathrm{M}, \mathrm{IC}_{50}$ HCT116-p53null $16 \mu \mathrm{M}$ ). In contrast, longer term clonogenic assays (where colonies were counted on days 16-18) showed no statistically significant differences in $\left[\left(\eta^{6}\right.\right.$ bip) $\mathrm{Ru}(\mathrm{en}) \mathrm{Cl}]^{+}$-induced loss of clonogenicity between both cell lines. ${ }^{[45]}$

Immunoblots demonstrated that $\left[\left(\eta^{6}\right.\right.$ bip) $\mathrm{Ru}(\mathrm{en}) \mathrm{Cl}]^{+}$induced accumulation of p53 and p21/WAF1 at $24 \mathrm{~h}$ and $48 \mathrm{~h}$ in a concentration-dependent manner and Bax at $48 \mathrm{~h}$. Cell cycle analysis demonstrated a mixed G1 and G2 growth arrest by $48 \mathrm{~h}$ in HCT116-WT and HCT116-Bax-null cells, but this growth arrest was not observed in the p53-null or in the p21/WAF1 null cells, indicating that the mixed G1/G2 growth arrest was p53- and p21/WAF1-dependent, but independent of Bax. ${ }^{[45]}$ Annexin-v apoptosis assays demonstrated the induction of increased apoptosis within $24 \mathrm{~h}$ of treatment in WT and p21/WAF1 null cells. ${ }^{[45]}$ On the other hand, no significant increase in apoptosis was induced in p53-null or bax-null cells. Whilst a sub-G1 peak appeared in the WT and p21/WAF1 null cells (consistent with the onset of internucleosomal DNA cleavage in late apoptosis), no sub-G1 peak appeared in the p53-null or bax-null cells. Thus p53 and Bax are required to mediate $\left[\left(\eta^{6}\right.\right.$-bip) $\mathrm{Ru}(\mathrm{en})$ $\mathrm{Cl}]^{+}$-induced apoptosis in human colon cancer cells within the first $48 \mathrm{~h}$ of treatment.

\subsubsection{Topiosomerase Activity}

Neither $\left[\left(\eta^{6}-p \text {-cym }\right) \mathrm{Ru}(\mathrm{en}) \mathrm{Cl}\right]^{+}$nor $\left[\left(\eta^{6}\right.\right.$ bip) $\mathrm{Ru}(\mathrm{en}) \mathrm{Cl}]^{+}$inhibited topiosomerase I (Topo I) or topiosomerase II (Topo II) enzyme activity, as characterized by the conversion of $\mathrm{pBR} 322$ plasmid DNA from the supercoiled conformation to the fully relaxed conformation, up to $50 \mu \mathrm{M}$ concentration. ${ }^{[16]}$ It is thus unlikely that inhibition of these enzymes is responsible for their anticancer activity. Interestingly inhibition of Topo II enzyme was thought to be critical for antiproliferative activity of the bifunctional $\mathrm{Ru}^{\mathrm{II}}$ arene $\left[\left(\eta^{6}-\mathrm{bz}\right) \mathrm{Ru}(\mathrm{DMSO})\right.$ $\left.\mathrm{Cl}_{2}\right],{ }^{[46]}$ which may act as a tri-functional ion in solution due to hydrolysis of the $\mathrm{Ru}-\mathrm{Cl}$ and $\mathrm{Ru}-\mathrm{DMSO}$ bonds. Thus monofunctional complexes e.g. $\left[\left(\eta^{6}-p\right.\right.$-cym $) \mathrm{Ru}(\mathrm{en})$ $\mathrm{Cl}]^{+}$may act in a different manner.

\subsubsection{Broad Activity Spectrum}

The in vitro activity of [( $\eta^{6}$-bip $) \mathrm{Ru}(\mathrm{en})$ $\mathrm{Cl}]^{+}$has been determined in a 14 cell panel line and the mean $\mathrm{IC}_{50}$ value was $3 \mu \mathrm{M}$ confirming that it has a broad spectrum of activity. ${ }^{[47]}$ Particular sensitivity ( $\mathrm{ca}$. tenfold lower than mean $\mathrm{IC}_{50}$ ) was noted in the breast cancer line 401NL and a nonsmall lung cancer cell line LXFL 529L. In addition the $\mathrm{IC}_{50}$ values against the human lung A549 and H520 cell lines were determined for $\left[\left(\eta^{6} \text {-bip }\right) \mathrm{Ru}(\mathrm{en}) \mathrm{Cl}\right]^{+}(3 \mu \mathrm{M}, 3.5$ $\mu \mathrm{M})$ and $\left[\left(\eta^{6} \text {-tha }\right) \mathrm{Ru}(\mathrm{en}) \mathrm{Cl}\right]^{+}(0.53 \mu \mathrm{M}, 0.5$ $\mu \mathrm{M})$ confirming the increase in potency as the arene ring size is increased. [47] The in vivo anticancer activity of these two complexes in A549 xenografts demonstrated a significant growth delay although studies showed that, especially for $\left[\left(\eta^{6}-\right.\right.$ tha $) \mathrm{Ru}(\mathrm{en})$ $\mathrm{Cl}]^{+}$, heptatoxicity may be a problem. ${ }^{[47]}$

\subsubsection{Reactions with Biologically Important Molecules}

3.2.6.1. L-Cysteine

The reaction of $\left[\left(\eta^{6} \text {-bip }\right) \mathrm{Ru}(\mathrm{en}) \mathrm{Cl}\right]^{+}$ and L-cysteine ( $1 \mathrm{mM}$ : $2 \mathrm{mM}$ ) has been followed by HPLC over a $48 \mathrm{~h}$ period and six products were identified. ${ }^{[48]}$ After the time period, $\mathrm{ca} .50 \%$ of the complex had still not reacted with L-cysteine. Two intermediates corresponding to the $\mathrm{S}$ - and $\mathrm{O}$-bound monosubstituted complexes initially increased in intensity for $12 \mathrm{~h}$ but disappeared after $48 \mathrm{~h}$. The final products, however, corresponded to unusual dinuclear ruthenium complexes from which half or all of the chelated ethylenediamine had been displaced to form predominantly $\quad\left[\left(\eta^{6}\right.\right.$-biphenyl $) \mathrm{Ru}\left(\mathrm{H}_{2} \mathrm{O}\right)$ $(\mu \mathrm{S}, \mathrm{N}$-L-cys $) \mathrm{Ru}\left(\eta^{6} \text {-biphenyl)(en) }\right]^{2+}$ but also $\left[\left(\eta^{6}\right.\right.$-biphenyl $) \mathrm{Ru}(\mathrm{O}, \mathrm{N}-\mathrm{L}-\mathrm{cys}-\mathrm{S})(\mathrm{S}-\mathrm{L}-$ Cys-N)Ru( $\eta^{6}$-biphenyl $\left.)\left(\mathrm{H}_{2} \mathrm{O}\right)\right]$. A small amount of oxidized [( $\eta^{6}$-biphenyl $) \mathrm{Ru}(\mathrm{O}$ $\left.\left.\mathrm{Cys}_{2} \mathrm{H}_{2}\right)(\mathrm{en})\right]^{2+}$ was also detected. Further studies ${ }^{[48]}$ showed that the course of the reaction of $\left[\left(\eta^{6}-\text { bip }\right) \mathrm{Ru}(\mathrm{en}) \mathrm{Cl}\right]^{+}$with $\mathrm{L}^{-}$ cysteine strongly depends on $\mathrm{pH}$ and the molar ratio of reagents. For example, below $\mathrm{pH} 5$ the final dinuclear adducts are detected but above this value, the hydrolyzed product is the predominant species. Furthermore when the mixture is at $\mathrm{pH}>7$, more L-cysteine was oxidized to cystine and so less bound to ruthenium.

\subsubsection{L-Methionine}

The reaction of $\left[\left(\eta^{6} \text {-bip }\right) \mathrm{Ru}(\mathrm{en}) \mathrm{Cl}\right]^{+}$ with L-methionine was analyzed in a similar manner, although only one product cor- 
responding to the S-bound [( $\eta^{6}$-biphenyl) $\mathrm{Ru}(\mathrm{S}-\mathrm{L}-\mathrm{MetH})(\mathrm{en})]^{2+}$ was detected. ${ }^{[48]}$ This reaction was slow with $\mathrm{at}_{1 / 2} c a .2 .3$ h. After 48 h, only approximately $27 \%$ of the ruthenium complex had reacted with Lmethionine.

\subsubsection{Histidine}

Reactions with $\left[\left(\eta^{6} \text {-bip) } \mathrm{Ru}(\mathrm{en}) \mathrm{Cl}\right]^{+}\right.$ and histidine have also been investigated, including the $1.6 \AA$ resolution crystal structure of the half-sandwich ruthenium $\left[\left(\eta^{6}-p\right.\right.$ cymene) $\mathrm{Ru}$ (lysozyme) $\mathrm{Cl}_{2}$ ], which showed selective ruthenation of $\mathrm{N} \varepsilon$ the imidazole ring of His 15. ${ }^{[49]}$ The reaction of [( $\eta^{6}$-bip) $\mathrm{Ru}(\mathrm{en}) \mathrm{Cl}]^{+}$and histidine $(2 \mathrm{mM}: 4 \mathrm{mM}$, $310 \mathrm{~K}$ ) reached equilibrium after approximately $24 \mathrm{~h}$, but only approximately $22 \%$ of the complex had reacted, with hydrolysis (59\%) being the preferred reaction. ${ }^{[50]}$ The products formed were confirmed by ESIMS and NMR as [( $\eta^{6}$-biphenyl)Ru(en) $(\mathrm{N} \varepsilon \text {-L-His }]^{2+}$ and $\left[\left(\eta^{6}\right.\right.$-biphenyl)Ru(en) $\mathrm{N} \delta$ L-His] ${ }^{2+}$

Thus overall the reactivity of [( $\eta^{6}$-bip) $\mathrm{Ru}(\mathrm{en}) \mathrm{Cl}]^{+}$towards amino acids follows the order L-Cys $\left(\mathrm{K}_{\mathrm{Cys}}=0.6 \mathrm{mM}^{-1}\right)>\mathrm{L}-\mathrm{Met}\left(\mathrm{K}_{\mathrm{Met}}\right.$ $\left.=0.34 \mathrm{mM}^{-1}\right)>$ L-His $\left(K_{\mathrm{His}}=0.14 \mathrm{mM}^{-1}\right)$.

\subsubsection{Cytochrome-c}

The reactions of $\left[\left(\eta^{6} \text {-bip }\right) \mathrm{Ru}(\text { en }) \mathrm{Cl}\right]^{+}$ with cytochrome-c, an electron transfer haem protein which contains two solventaccessible histidine residues, His26 and His33, with [( $\eta^{6}$-bip)Ru(en-15N)Cl]+ gave two mono-ruthenated protein adducts that were thought to contain ruthenium bound to the $\mathrm{N}$-terminus or to a carboxylate group. [50] The reaction reached equilibrium after approximately $2 \mathrm{~h}$, by which time approximately $50 \%$ of cytochrome c had been ruthenated.

Competitive reactions of $\left[\left(\eta^{6}\right.\right.$-bip $)$ $\mathrm{Ru}(\mathrm{en}) \mathrm{Cl}]^{+}(0.2 \mathrm{mM})$ with the 14 -mer oligonucleotide d(TATGTACCATGTAT) (0.1 $\mathrm{mM})$ in the absence and presence of cytochrome-c $(0.1 \mathrm{mM})$ or histidine $(0.4 \mathrm{mM})$ showed that the presence of either of these two reagents had little effect on the reaction of $\left[\left(\eta^{6} \text {-bip }\right) \mathrm{Ru}(\mathrm{en}) \mathrm{Cl}\right]^{+}$with the oligonucleotide, and that in all cases $c a .90 \%$ of the oligonucleotide had reacted to give rise to mono-ruthenated and diruthenated adducts. [50] This suggests that in the cells, DNA (or RNA) may be the favoured reaction site for this class of organometallic ruthenium(II) ethylenediamine anticancer complex.

\subsubsection{Glutathione}

Similar competitive reactions between $\left[\left(\eta^{6} \text {-bip) } \mathrm{Ru}(\mathrm{en}) \mathrm{Cl}\right]^{+}\right.$glutathione and cGMP have been studied under physiologically-relevant conditions ([( $\eta^{6}$-bip $\left.) \mathrm{Ru}(\mathrm{en}) \mathrm{Cl}\right]+20 \mu \mathrm{M}$, 250 mol equiv. GSH, 25 mol equiv. cGMP, $10 \mathrm{mM}$ phosphate buffer, $22 \mathrm{mM} \mathrm{NaCl}, 310$ K). [51] Initially, reactions with GSH alone under physiologically relevant conditions yielded two main products: the monoruthenated $\mathrm{GSH}$ adduct [( $\eta^{6}$-bip)Ru(en)SG] ${ }^{+}$and, surprisingly, the corresponding oxidized sulfenato complex $\left[\left(\eta^{6} \text {-bip }\right) \mathrm{Ru}(\mathrm{en}) \mathrm{SOG}\right]^{+}$, the intensity of which increased from about $11 \%$ of the total ruthenium after $12 \mathrm{~h}$ to $19 \%$ after $48 \mathrm{~h}$. The presence of this adduct was confirmed by ESI-MS (m/z 638.1, calcd $\mathrm{m} / \mathrm{z} 638.1$ for $\left\{\left(\eta^{6} \text {-bip)Ru(en)SOG }+\mathrm{H}\right\}^{+}\right.$ and infrared spectroscopy (band at 1018 $\mathrm{cm}^{-1}$ assignable to $\mathrm{S}=\mathrm{O}$ stretching). The oxygen atom is thought to originate from molecular $\mathrm{O}_{2}$ since reactions performed under $\mathrm{O}_{2}$ yielded a higher proportion of sulfenato adduct compared to those carried out under Ar. In the competitive reactions (reactions purged with $\mathrm{N}_{2}$ to minimize oxygen content) after $30 \mathrm{~h}$ of reaction three products formed corresponding to $\left[\left(\eta^{6}\right.\right.$-bip) $R u(e n)$ $\mathrm{SG}]^{+},\left[\left(\eta^{6} \text {-bip)Ru(en)SOG }\right]^{2+}\right.$ and $\left[\left(\eta^{6}\right.\right.$-bip) $\mathrm{Ru}(\mathrm{en}) \mathrm{cGMP}-\mathrm{N}(7)]^{+}$in ratios of 36:30:26. A similar reaction sampled in air yielded $\left[\left(\eta^{6} \text {-bip)Ru(en)cGMP-N(7) }\right]^{2+}\right.$ as the major product after $72 \mathrm{~h}$. Thus the thiolato adduct appeared to be oxygenated by $\mathrm{O}_{2}$ to the sulfenato complex and this sulfenato ligand appeared to be readily displaced by cGMP to give the cGMP adduct as the dominant product of the reaction. This implies that whilst the sulfenato ligand is readily substituted by cGMP, the thiolato ligand is not. This observed oxidation of the coordinated glutathione to the sulfenate appears to be a facile route for displacement of S-bound glutathione, since a $\mathrm{Ru}-\mathrm{S}$ (sulfenate) bond would be expected to be weaker than a $\mathrm{Ru}-\mathrm{S}$ (thiolate) bond. ${ }^{[52]}$

\subsubsection{Nicotinamide Adenine Dinucle- otide $N A D^{+}$}

$\mathrm{Ru}^{\mathrm{II}}$ arenes can catalyze the regioselective reduction of nicotinamide adenine dinucleotide $\mathrm{NAD}^{+}$by formate to form $1,4-\mathrm{NADH}$ in aqueous solutions. ${ }^{[53]} \mathrm{NAD}^{+}$ is an important co-enzyme found in cells and is involved in the transfer of electrons. A plausible mechanism of reduction is thought to involve formation of the $\mathrm{Ru}^{\mathrm{II}}$ hydride complex $\left[\left(\eta^{6} \text {-arene }\right) \mathrm{Ru}(\mathrm{en}) \mathrm{H}\right]^{+}$with formate as the hydride donor and then transfer of hydride to $\mathrm{NAD}^{+}$regenerates $\left[\left(\eta^{6}\right.\right.$-arene $)$ $\left.\mathrm{Ru}(\mathrm{en}) \mathrm{H}_{2} \mathrm{O}\right]^{2+}$. For example, the complex $\left[\left(\eta^{6}-\mathrm{hmb}\right) \mathrm{Ru}(\mathrm{en}) \mathrm{Cl}\right]^{+}$can reduce $\mathrm{NAD}^{+}$ with a maximum TOF of $1.46 \mathrm{~h}^{-1}$ and a $\mathrm{K}_{\mathrm{m}}$ of $58 \mathrm{mM}$. Other organometallic complexes such as $\left[\mathrm{Cp} * \mathrm{Rh}(\right.$ bipy $)\left(\mathrm{H}_{2} \mathrm{O}\right]^{2+}$ have higher TOF (77.5 h-1) and higher $\mathrm{K}_{\mathrm{m}}$ values (140 $\mathrm{mM}) .{ }^{[54]}$ The rate was found to be independent of $\mathrm{NAD}^{+}$and the rate-determining step is hydride transfer from formate to ruthenium. Cell growth of A549 cancer cells was unaffected by formate concentrations up to 2.5 $\mathrm{mM}$. The cytotoxicity of the ruthenium complexes appeared to be unaffected by the coadministration of formate. For the proposed in vivo catalysis is to succeed, more active catalysts are probably required.

\subsection{Other Chelating Nitrogen Ligands}

\subsubsection{Aliphatic $\sigma$-Donor Diamines}

Structure-activity relationships have revealed that replacement of the ethylenediamine chelating ligand with the N,Ndimethyl-ethylenediamine derivative result in a dramatic loss of cytotoxicity (e.g. [ $\left(\eta^{6}-\right.$ $p$-cym $) \mathrm{Ru}($ en $) \mathrm{Cl}]^{+}, \mathrm{IC}_{50}=5 \mu \mathrm{M},\left[\left(\eta^{6}\right.\right.$-bip $)$ $\left.\mathrm{Ru}(\mathrm{N}, \mathrm{N} \text {-dimethyl-en) } \mathrm{Cl}]^{+}, \mathrm{IC}_{50}>100 \mu \mathrm{M}\right)$. [10] This may be related to the inability of the complex to form strong stereospecific $\mathrm{C}(6) \mathrm{O} . . \mathrm{HN}$ hydrogen bonds with guanine bases, an interaction thought to stabilize and enhance the recognition (vide supra). The reaction of this $\left[\left(\eta^{6}\right.\right.$-bip $) \mathrm{Ru}(\mathrm{N}, \mathrm{N}$-dimethyl-en)Cl] ${ }^{+}$with $9-E t-G$ was followed by ${ }^{1} \mathrm{H}$ NMR spectroscopy and no binding was observed. Thus steric effects of the methyl groups (preventing approach by $9-\mathrm{Et}-\mathrm{G}$ ) as well as a lack of potential hydrogen bonding towards DNA bases may contribute to the loss of activity. ${ }^{[10]}$

Changing the chelate from ethylenediamine to propylene-diamine (prop) (i.e. changing the chelate ring size from five to six members) ring did not affect the cancer cell cytotoxicity $\left[\left(\eta^{6}-p \text {-cym }\right) \mathrm{Ru}(\mathrm{en}) \mathrm{Cl}\right]^{+} \mathrm{IC}_{50}=$ $10 \mu \mathrm{M},\left[\left(\eta^{6}-p \text {-cym)Ru(prop)Cl }\right]^{+} \mathrm{IC}_{50}=\right.$ $10 \mu \mathrm{M} .{ }^{[10]}$ However, addition of a polar $\mathrm{OH}$ substituent on the propylenediamine backbone decreased the activity. Further derivativisation of en ligands has varying effects on the cytotoxicity; mono-methylation of en does not affect $\mathrm{IC}_{50}$ values, whereas dialkylation via ring formation lowers the activity three-fold and cyclisation of en to give homopiperazine results in an inactive compound $\left(\mathrm{IC}_{50}>50 \mu \mathrm{M}\right)$. $^{[10]}$

\subsubsection{Aromatic $\sigma$-Donor Diamines}

Good cytotoxicity is retained when ethylenediamine ligands are replaced with chelating 1,2-diaminobenzene ligands. ${ }^{[10]}$ A slightly different trend was observed with cytotoxicity on changing the arene in 1,2-diaminobenzene complexes; the $\mathrm{IC}_{50}$ value increased in the order biphenyl (5 $\mu \mathrm{M})$, dha $(7 \mu \mathrm{M})<p$-cymene $(11 \mu \mathrm{M})$, tetralin $(13 \mu \mathrm{M})<$ tha $(23 \mu \mathrm{M})$. Interestingly these complexes are able to overcome cross-resistance to the $2780 \mathrm{AD}$ cell line, in contrast to en complexes, see Fig. 4. ${ }^{[17]}$

\subsubsection{Dinuclear Chelating Ligands}

The dinuclear complex $\left[\left(\left(\eta^{6}\right.\right.\right.$-bip $)$ $\left.\mathrm{RuCl}(\mathrm{en}))_{2}-\left(\mathrm{CH}_{2}\right)_{6} \mathrm{Cl}\right]^{2+}$, in which two $\mathrm{Ru}^{\mathrm{II}}$ arene centres are linked with a flexible chain contains four stereogenic centres $(\mathrm{Ru}$, $\mathrm{N}, \mathrm{N}, \mathrm{Ru}$ ) which gives rise to ten potential configurations..[55] In aqueous solution the complex exists as a diastereomeric mixture of $\mathrm{AA} / \mathrm{AB} / \mathrm{BB}(\mathrm{A}=(\mathrm{R} * \mathrm{RuR} * \mathrm{~N}), \mathrm{B}=$ $(\mathrm{S} * \mathrm{RuR} * \mathrm{~N}))$ as 67.7:24.0:8.3 and hydrolysis of $\mathrm{Ru}-\mathrm{Cl}$ appears to have a negligible influence on the configurational abundance ratios. The $A(R * R u R * N)$ configuration 


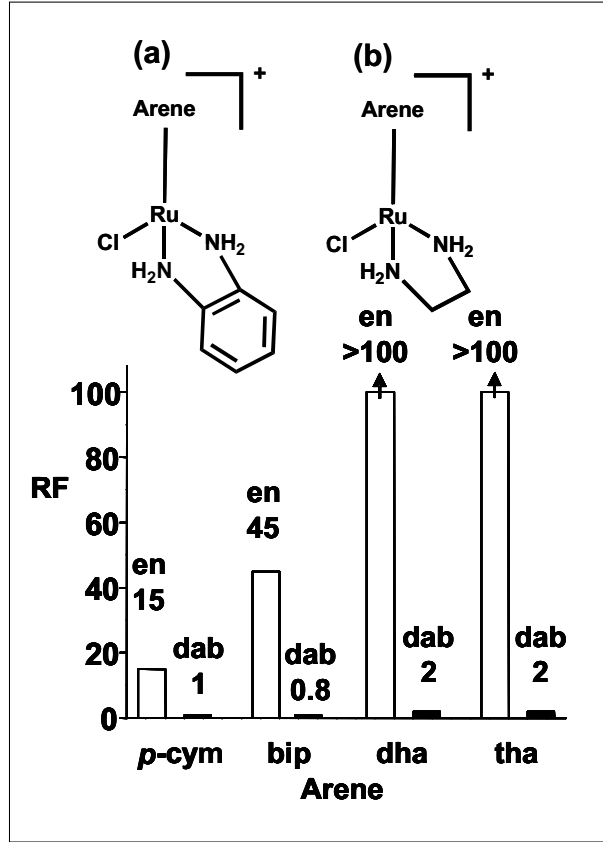

Fig. 4. Effect of changing the chelating ligand from ethylenediamine (en) to 1,2-diaminobenzene on the cytotoxicity towards $A 2780$ and $2780 A D$ cells for ruthenium complexes $\left[\left(\eta^{6}\right.\right.$-arene) $R u(N, N)$ $\mathrm{Cl}]^{+}$containing the arenes $p$-cym, bip, dha and tha. The resistance factor $(\mathrm{RF})=\mathrm{IC}_{50}(2780 \mathrm{AD}) /$ $\mathrm{IC}_{50}\left(2780^{\mathrm{AP}}\right)$.

is thermodynamically preferred. Analysis of the complex after reaction with 9-EtG (to give $\left[\left(\left(\eta^{6}\right.\right.\right.$-bip) $\mathrm{Ru}(\mathrm{N}(7)-9-\mathrm{EtG})(\mathrm{en}) 2$ $\left.\left.\left(\mathrm{CH}_{2}\right)_{6} \mathrm{Cl}\right]^{2+}\right)$ showed that the $\mathrm{B}(\mathrm{S} * \mathrm{RuR} * \mathrm{~N})$ configuration is highly favoured ( $c a .95 \%)$ due to the A configuration being strongly destabilized by steric interactions between $G$ and the en alkyl substituent whereas the $\mathrm{B}$ configuration is stabilized by stereospecific hydrogen bonding between en $\mathrm{NH}$ and $\mathrm{G} \mathrm{O}(6)$. Thus upon reacting with $9-\mathrm{EtG}$, a facile epimerization at $\mathrm{Ru} / \mathrm{N}$ centres occurs to allow dynamic switching between these configurations leading to a high selectivity in the formation of $G$ adducts. ${ }^{[55]}$ Substitution of an en NH proton by an alkyl group had little effect on the kinetics of the reactions with CT-DNA indicating that the alkyl substituent does not significantly hinder $G$ binding when epimerization is facile.

DNA-directed RNA synthesis experiments supported that $\left[\left(\left(\eta^{6}-\right.\right.\right.$ bip $)$ Ru(en) $\left.\mathrm{Cl})_{2}-\left(\mathrm{CH}_{2}\right)_{6}\right]^{2+}$ coordinates preferentially to $\mathrm{G}$ bases of DNA and it was assumed that this binding involves dynamic chiral recognition, with preferential formation of the B configuration and this allows $84 \%$ to coordinate to the DNA. ${ }^{[5]}$ Interestingly this dinuclear complex inhibits RNA synthesis more effectively than the mononuclear complex $\left[\left(\eta^{6} \text {-bip }\right) \mathrm{Ru}(\mathrm{en}) \mathrm{Cl}\right]^{+}$. Binding to CT-DNA induced a positive CD band centred at 370-380 nm suggesting intercalation of the extended phenyl ring into DNA (as observed previously for the mononuclear complexes (vide supra)). The dinuclear complex was able to unwind $\mathrm{pS} /$ P73KB DNA with an angle of $31^{\circ}$ which was over double that for $\left[\left(\eta^{6}\right.\right.$-bip $) \mathrm{Ru}(\mathrm{en})$ $\mathrm{Cl}]^{+}\left(14^{\circ}\right)$ suggesting that cross-linking of DNA and perturbation of DNA structure by the two pendant phenyl rings is important. Evidence of cross-linking came from the observations

i) that the efficiency of the interstrand cross-linking on a 213-bp EcoRI fragment of pSP73 randomly modified by the dinuclear complex was similar to that of the known DNA cross-linker cisplatin and

ii) a site-specifically ruthenated 20-mer formed a 1,3-GG interstrand cross-link (20\% frequency) and 1,2-GG and 1,2GTG cross-links were also detected. ${ }^{[55]}$

\subsubsection{Chelating $\sigma$-Donor $\pi$-Acceptor Ligands}

\subsubsection{Bipyridine and Bipyridine Derivative Ligands}

Ruthenium(II) chloride arenes with indan as the arene containing 2,2'-bipyridine, 4,4 '-bipyridine derivatives or phenanthroline (phen) as the chelating nitrogen ligand are all inactive towards the A2780 cancer cell line $\left(\mathrm{IC}_{50}>50 \mu \mathrm{M}\right){ }^{[10]}$ The reason for inactivity may be the absence of suitable $\mathrm{NH}$ donors to form favourable hydrogen bond interactions with guanine and the increased bulk around the ruthenium, perhaps preventing binding to $\mathrm{G}$, as observed for the $\left[\left(\eta^{6} \text {-bip }\right) \mathrm{Ru}(\mathrm{N}, \mathrm{N} \text {-dimethyl-en }) \mathrm{Cl}\right]^{+}$ complexes. The rate of hydrolysis may also be slower and this may reduce cytotoxicity; slow hydrolysis has been reported for $\left[\left(\eta^{6}\right.\right.$ arene) $\mathrm{Ru}($ phen $) \mathrm{Cl}]^{+}$complexes and isolation of aqua adducts was assisted by the use of Ag-salts, ${ }^{[56]}$ and the incorporation of bipy into $\left[\left(\eta^{6}-\mathrm{bz}\right) \mathrm{Ru}(\mathrm{en}) \mathrm{OH}_{2}\right]^{+}$slows down the rate of water exchange by a factor of 174 (c.f. $\left.\left[\left(\eta^{6}-\mathrm{bz}\right) \mathrm{Ru}\left(\mathrm{OH}_{2}\right)_{3}\right]^{2+}\right) .{ }^{[13]}$

\subsubsection{Phenylazopyridine Ligands}

Ruthenium(II) arene chloride complexes containing chelating 2-phenylazopyridine (azpy) ligands have been synthesized and evaluated for cytotoxicity against the A2780 human ovarian and A549 human lung cancer cell lines and moderate cytotoxicity was observed for some derivatives $\left(\mathrm{IC}_{50}\right.$ values 18-88 $\mu \mathrm{M})$. $^{[57]}$ These phenyazopyridine ligands are superior in terms of $\pi$-acceptor ability compared to bipyridine. ${ }^{[58]}$ The complexes undergo a mixture of slow hydrolysis and arene loss $\left(\mathrm{t}_{1 / 2} 9-21 \mathrm{~h}\right)$ at physiologically relevant concentrations $(100 \mu \mathrm{M}$, $310 \mathrm{~K})$. Arene loss is rarely observed for $\mathrm{Ru}^{\mathrm{II}}$ arenes, since the ruthenium-arene bonds are usually considered to be inert to hydrolysis. Literature reports of arene loss for $\left[\left(\eta^{6}-b z\right) \mathrm{Ru}(\text { bipy }) \mathrm{Cl}\right]^{+}$exist, but much stronger reaction conditions are required. ${ }^{[59]}$ Comparison of the ruthenium-arene centroid distances in the X-ray crystal struc- tures of $\left[\left(\eta^{6} \text {-bip)Ru(en)Cl }\right]^{+}\right.$and $\left[\left(\eta^{6}\right.\right.$-bip $)$ $\mathrm{Ru}(\text { azpy) } \mathrm{Cl}]^{+}$reveals that the arene is not as strongly bound to the ruthenium in the azpy complex (ruthenium-arene centroid distance 1.662(3) $\AA$ vs 1.707(2) $\AA$ ) and this suggested that the arene and the chelating azo ligand are effectively acting as competitive $\pi$-acceptors for $\mathrm{Ru} 4 \mathrm{~d}^{6}$ electrons resulting in a more labile arene.

The inertness towards hydrolysis may indicate that these complexes have a novel mechanism of action; surprisingly replacement of the chloride ligand by iodide to give $\left[\left(\eta^{6} \text {-arene }\right) \mathrm{Ru}(\text { azpy-NMe }) \mathrm{I}\right]^{+}$or $\left[\left(\eta^{6}-\right.\right.$ arene) $\mathrm{Ru}(\text { azpy-OH)I }]^{+}$results in complexes that are inert to both hydrolysis and arene loss over $24 \mathrm{~h}(310 \mathrm{~K})$ and yet display good cytotoxicity in both the A2780 and A549 cancer cell lines. ${ }^{[60]}$ Work into the mechanism of action of these complexes is currently being investigated.

The stability of $\mathrm{Ru}(\mathrm{II})$-arene bonds towards hydrolysis can be increased by changing the chelating phenylazopyridine ligand to a phenylazopyrazole derivative. ${ }^{60]}$ The pyrazole substituent renders the whole ligand a less efficient $\pi$-acceptor since pyrazole is formally classed as a five-membered $\pi$-excessive/ $\pi$-neutral heterocycle, c.f pyridine (six-membered $\pi$-electron deficient). Rates for hydrolysis (determined by UV-Vis spectroscopy $50 \mu \mathrm{M}, 310 \mathrm{~K}, \mathrm{pH}$ 2.25 ) are $2-2.7 \mathrm{~h}$ (arene $=\mathrm{bz}$, bip, tetralin, $p$-cym). In the biphenyl case slow arene loss is also observed.[57,61] These complexes were found to be more cytotoxic towards A2780 ovarian and A549 lung cancer cell lines than their phenylazopyridine analogues. ${ }^{[57]}$ Interestingly the $\mathrm{pK}_{\mathrm{a}}$ of the coordinated water in $\left[\left(\eta^{6}-p\right.\right.$-cym $)$ Ru(azpy$\left.\mathrm{NMe}_{2}\right)\left(\mathrm{OH}_{2}\right]^{2+}$ is 4.60 so at physiological $\mathrm{pH}$ the complex exists almost exclusively in the hydroxo form. Reaction of $\left[\left(\eta^{6}-p-\right.\right.$ cym) $\mathrm{Ru}\left(\right.$ azpy- $\left.\mathrm{NMe}_{2}\right)\left(\mathrm{OH}_{2}\right]^{2+}$ with one mol equiv of $9 \mathrm{EtG}$ at $310 \mathrm{~K}$ over $24 \mathrm{~h}$ gave $c a$. $26 \%$ binding and equillibrium was reached after $c a .3 \mathrm{~h}$.

\section{Ruthenium(II)-Arene Complexes Containing Chelating $\sigma$-Donor $\pi$-Donor Oxygen Ligands}

\subsection{Acetylacetonate Ligands}

Changing the chelating ligand from a dinitrogen $\sigma$-donor such as ethylenediamine to a $\sigma$-donor $\pi$-donor oxygen chelating ligand dramatically changes the reactivity of the ruthenium arene with respect to hydrolysis, cytotoxicity and DNA base specificity. The chemistry of ruthenium(II) arenes containing the anionic O,O-chelating ligand acetylacetonate (acac) has been reported. ${ }^{62]}$ Complexes such as $\left[\left(\eta^{6}-p\right.\right.$-cym) Ru(acac) $\mathrm{Cl}$ hydrolyze rapidly in water and equilibrium is reached in less than $5 \mathrm{~min}(298 \mathrm{~K})$. The $\mathrm{pK}_{\mathrm{a}}$ of the coordinated water molecule 
in the aqua adduct $\left[\left(\eta^{6}-p\right.\right.$-cym $) \mathrm{Ru}(\mathrm{acac})$ $\left.\mathrm{OH}_{2}\right]^{+}$is 9.41 , which means that at physiological $\mathrm{pH}$ ( $\mathrm{pH}$ 7.4) the complex exists almost exclusively in the reactive aqua form. The increased $\mathrm{pK}_{\mathrm{a}}$ value is due to the acac ligands being strong $\sigma$-donor and $\pi$-donors towards the $\mathrm{Ru}^{\mathrm{II}}$ centre, increasing the electron density and hence decreasing the acidity of the ruthenium centre. ${ }^{[63]}$ In the reaction of $\left[\left(\eta^{6}-p-c y m\right) \mathrm{Ru}(\mathrm{acac}) \mathrm{Cl}\right]$ with guanosine ( $2 \mathrm{mM} \mathrm{1:1)}$ at equilibrium $c a$. $80 \%$ of the guanosine is bound. A similar result is obtained for adenosine ( $\mathrm{ca}$. $80 \%$ is bound ratio of $\operatorname{adoN}(7): \operatorname{adoN}(1) 4: 1)$. This selectivity is in stark contrast to the corresponding ethylenediamine analogues for which negligible binding to adenosine is observed (vide supra). In competitive reactions with adenosine and guanosine at equimolar ratios, the ratios of $\mathrm{Ru}^{\mathrm{II}}$ bound to guanosine/adenosine is $c a$. 4:5 suggesting a slight preference for adenosine over guanosine. The formed adducts are, however, kinetically labile and nucleoside exchange reactions within the system are facile. The complex $\left[\left(\eta^{6}-p\right.\right.$-cym $)$ $\mathrm{Ru}(\mathrm{acac}) \mathrm{Cl}$ ] does not form adducts with cytidine and thymidine over the $\mathrm{pH}$ range of 2.4-10.4 which, again, is in contrast to the en analogues. This lack of binding may be due to unfavourable steric and electronic interactions of the nucleobase carbonyl groups with the acac ligands.

The complexes $\left[\left(\eta^{6}\right.\right.$-arene $) \mathrm{Ru}(\mathrm{acac})$ $\mathrm{Cl}$ ] (arene $=$ pcym, bip, bz, indan and dha) exhibit moderate activity towards A2780 ovarian cancer cells $\left(\mathrm{IC}_{50} 19-70 \mu \mathrm{M}\right)$. $^{[10}$ In general the acac complexes hydrolyze rapidly and have poor aqueous solubility. The reason for the reduced cytotoxicity compared to the en analogues may in part be due to the protonation and irreversible displacement of the chelated acac derivative under some conditions; the aqueous solution chemistry of the osmium analogue $\left[\left(\eta^{6}-p\right.\right.$-cym $)$ Os $\left.(\mathrm{acac}) \mathrm{Cl}\right]$ was studied using conditions mimicking the cytotoxicity testing ${ }^{[64]}$ and this revealed that only one species was present, assignable to the hydroxo-bridged dimer $\left[\left(\eta^{6}-p\right.\right.$-cym $) \mathrm{Os}\left(\mu_{2}\right.$ OD) $\left.{ }_{3} \mathrm{Os}\left(\eta^{6}-p-c y m\right)\right]^{+}$, i.e. acac is readily lost from the complex. This complex is inactive towards the A2780 cancer cell line $\left(\mathrm{IC}_{50}>50 \mu \mathrm{M}\right)$.

\subsection{Maltolato (mal) Ligands}

Both $\left[\left(\eta^{6}-p\right.\right.$-cym $\left.) \mathrm{Ru}(\mathrm{mal}) \mathrm{Cl}\right]$ and the corresponding osmium complex $\left[\left(\eta^{6}-p\right.\right.$ cym)Os(mal) $\mathrm{Cl}]$ complexes are non-toxic towards A549 human lung and A549 human ovarian cells. ${ }^{65]}$ The inactivity of these complexes is due to hydroxo-bridged dimer formation, which persists at low metal concentrations, see Fig. 5. This feature is also observed in the acac derivatives $\left[\left(\eta^{6}-p-\right.\right.$ cym) $\mathrm{Ru}(\mathrm{acac}) \mathrm{Cl}]$ and $\left[\left(\eta^{6}-p\right.\right.$-cym $) \mathrm{Os}(\mathrm{acac})$ $\mathrm{Cl}$. The most stable complex towards dimer formation is $\left[\left(\eta^{6}-p\right.\right.$-cym $\left.) \mathrm{Ru}(\mathrm{mal}) \mathrm{Cl}\right]$ and the least stable $\left[\left(\eta^{6}-p\right.\right.$-cym $\left.) \mathrm{Os}(\mathrm{acac}) \mathrm{Cl}\right]$.

Although introduction of the five-membered mal chelate ring provides stabiliza-

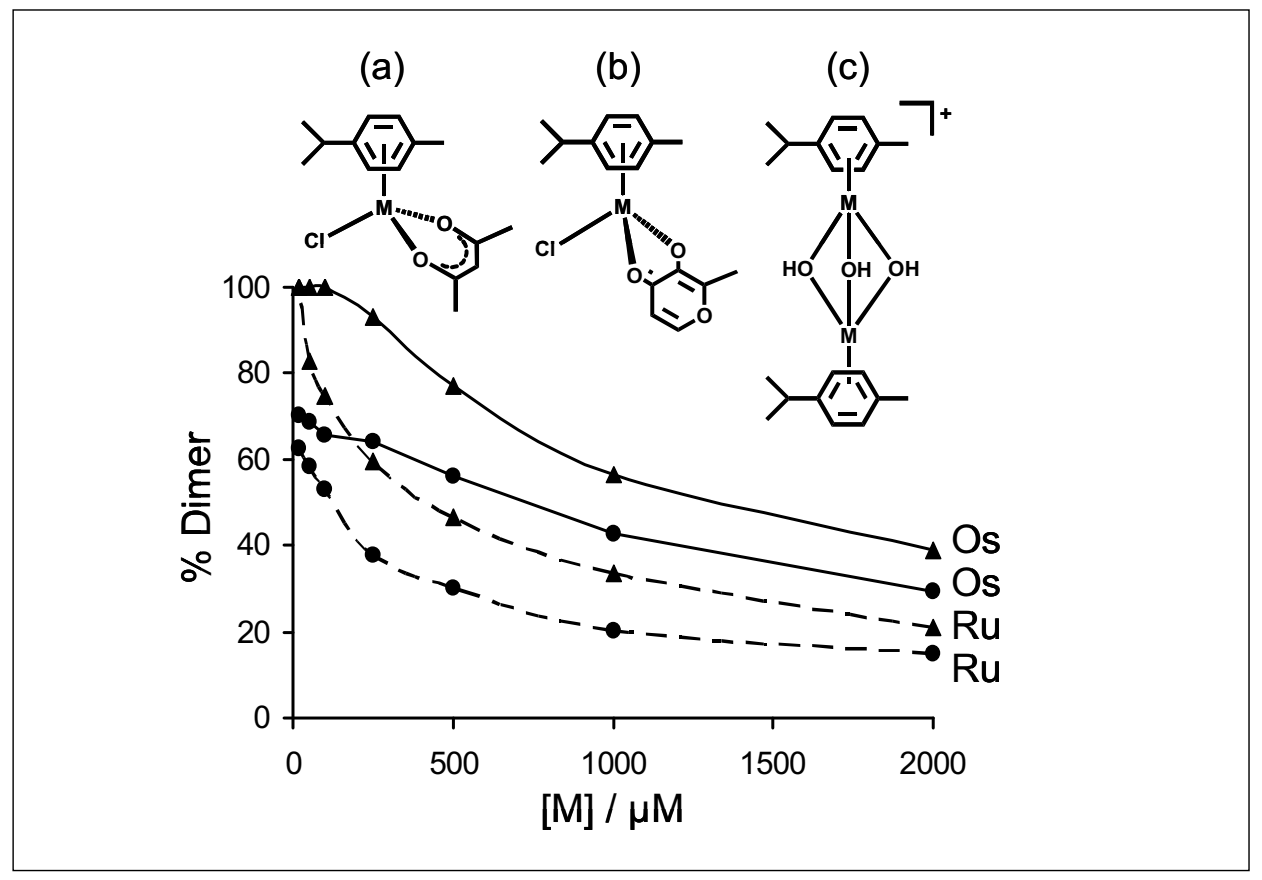

Fig. 5. Dimer formation in $\left[\left(\eta^{6}-p-c y m\right) M(\right.$ acac $\left.)(C l)\right]$ and $\left[\left(\eta^{6}-p-c y m\right) M(\right.$ mal) $(C l)]$ systems $(M=R u, O s)$. Upper: the molecular structures of (a) $\left[\left(\eta^{6}-p-c y m\right) M(a c a c)(C l)\right]$, (b) $\left[\left(\eta^{6}-p-c y m\right) M(m a l)(C l)\right]$ and the triply hydroxo-bridged dimer (c) $\left[\left(\eta^{6}-p-c y m\right) M(O H)_{3} M\left(\eta^{6}-p-c y m\right)\right]^{+}$Lower: Dependence on the formation of hydroxo-bridged dimers on total metal concentrations of the ruthenium and osmium-mal and acac complexes in $\mathrm{D}_{2} \mathrm{O}$ after incubation at $310 \mathrm{~K}$ for $24 \mathrm{~h}$. - - - $\mathrm{M}=\mathrm{Ru},--$ acac, $\bullet=$ mal

tion towards hydroxo-bridged dimer formation compared with the six-membered acac ring, the dominant species at biologically relevant conditions are still the hydroxobridged dimers. A possible mechanism for dimer formation of $\left[\left(\eta^{6}-p\right.\right.$-cym $\left.) \mathrm{Ru}(\mathrm{mal}) \mathrm{Cl}\right]$ and $\left[\left(\eta^{6}-p\right.\right.$-cym $\left.) \mathrm{Os}(\mathrm{mal}) \mathrm{Cl}\right]$ may involve protonation of one of the maltolate oxygen atoms followed by ring opening and eventual loss of maltolate.[65]

Both $\left[\left(\eta^{6}-p\right.\right.$-cym $\left.) \mathrm{Ru}(\mathrm{mal}) \mathrm{Cl}\right]$ and $\left[\left(\eta^{6}-p\right.\right.$ cym)Os(mal)Cl] react rapidly with $\mathrm{N}(7)-\mathrm{G}$ (guanosine and 9EtG) and $\mathrm{N}(1)$ and $\mathrm{N}(7)$ of A (adenosine). Isolation of [ $\left(\eta^{6}-p\right.$-cym) $\mathrm{Os}(\mathrm{mal})(\mathrm{EtG})]^{+}$and subsequent stability studies (concentrations $20 \mu \mathrm{M}-2 \mathrm{mM}$, after $24 \mathrm{~h}$ at $310 \mathrm{~K}$ ) revealed that at higher concentrations the Os-N(7)-9EtG complex persisted ( $c a .69 \%$ of $\left[\left(\eta^{6}-p\right.\right.$-cym)Os $(\mathrm{mal})$ $(\mathrm{EtG})]^{+}$at $\left.2 \mathrm{mM}\right)$, but that as the concentration of osmium decreased, the hydroxobridged dimer increased in intensity $(0 \%$ of $\left[\left(\eta^{6}-p \text {-cym }\right) \operatorname{Os}(\mathrm{mal})(\mathrm{EtG})\right]^{+}$at $\left.20 \mu \mathrm{M}\right) .{ }^{665]}$ In situ preparation of $\left[\left(\eta^{6}-p\right.\right.$-cym $) \mathrm{Ru}(\mathrm{mal})$ $(\mathrm{EtG})]^{+}$and $\left[\left(\eta^{6}-p \text {-cym }\right) \mathrm{Os}(\mathrm{mal})(\mathrm{EtG})\right]^{+}$ from the chloride analogues and equimolar 9etG in aqueous solution allowed the formation constants to be determined (log $\mathrm{K}$ $=4.41(\mathrm{Os}), 3.87(\mathrm{Ru}))^{\left[{ }^{[65]} \text { Whilst Os binds }\right.}$ more strongly than $\mathrm{Ru}$, the binding is only moderate in strength, and the formation of hydroxo-bridged dimers provides a driving force for the dissociation of nucleobase adducts since the dimers appear to be the thermodynamically stable products from the dissociation of nucleobases.

Ruthenium $^{\mathrm{II}}$ arene complexes containing the monoanionic $\mathrm{O}, \mathrm{O}$ chelating ligands acetato and tropolonato have been synthesised and their interactions with nucleobases studied.[66]

\section{Ruthenium(II) Arene Complexes Containing Mixed Chelating Nitrogen-Oxygen Ligands}

Several ruthenium arene complexes of the type $\left[\left(\eta^{6}-p\right.\right.$-cymene $\left.) \mathrm{Ru}(\mathrm{N}, \mathrm{O}) \mathrm{Cl}\right]$ containing $\mathrm{N}, \mathrm{O}$ chelating ligands such as gylcine, L-alanine, D-alanine, $\beta$-alanine, $\mathrm{L}$ phenylalanine, D-phenylalanine and 8-hydroyxquinoline have all been found to be inactive towards the A2780 human ovarian cancer cell line $\left(\mathrm{IC}_{50}>100 \mu \mathrm{M}\right)$. $^{[10]}$

The $\mathrm{pK}_{\mathrm{a}}$ of the coordinated water in $\left[\left(\eta^{6}-p \text {-cymene }\right) \mathrm{Ru}(\text { glycine- } \mathrm{N}, \mathrm{O}) \mathrm{H}_{2} \mathrm{O}\right]^{+}$is 8.25 , hence at physiological $\mathrm{pH}$ the complex will exist in the more reactive aqua form (c.f. the inactive hydroxo form). The hydrolysis of $\left[\left(\eta^{6}-p\right.\right.$-cymene $) \mathrm{Ru}($ glycine$\mathrm{N}, \mathrm{O}) \mathrm{Cl}$, studied by ${ }^{1} \mathrm{H} \mathrm{NMR}$, was very fast (equilibrium reached in $<5 \mathrm{~min}$ ) and contained two sets of peaks indicating that at equilibrium, aqua and chlorido adducts exist in a 3.7:1 ratio. ${ }^{[10]}$ The addition of 500 $\mathrm{mM} \mathrm{NaCl}$ was not sufficient to suppress 
the hydrolysis fully, in contrast to the corresponding en-type complexes. The higher stability of the aqua complex may account for the lack of observed cytotoxicity since this highly reactive aqua complex may be deactivated by reaction with biomolecules before it reaches its target site. Such a phenomenon is observed for PdII analogues of active $\mathrm{Pt}^{\mathrm{II}}$ complexes which are inactive on account of their higher reactivity. ${ }^{67]}$

Sheldrick and Heeb have previously reported that reaction of $\left[\left(\eta^{6}-\mathrm{C}_{6} \mathrm{H}_{6}\right) \mathrm{Ru}(\mathrm{L}-\right.$ alanine) $9 \mathrm{EtG}$ ] with $9 \mathrm{EtG}$ afforded the complex $\left[\left(\eta^{6}-\mathrm{C}_{6} \mathrm{H}_{6}\right) \mathrm{Ru}(\mathrm{L}\right.$-alanine $\left.) 9 \mathrm{EtG}\right] \mathrm{Cl} .{ }^{[68]}$ In this report it was mentioned that $\left[\left(\eta^{6}-\right.\right.$ $\left.\mathrm{C}_{6} \mathrm{H}_{6}\right) \mathrm{Ru}$ (L-proline)Cl] showed significant activity towards P388 leukaemia, but no data on this were published.

Recently we have reported that osmium arene analogues containing anionic N,O chelating ligands picolinate (pico) or 8-hydroxyquinolate (oxine) ([( $\eta^{6}$-bip)Ru(pico) $\mathrm{Cl}],\left[\left(\eta^{6}-p-c y m\right) \mathrm{Ru}(\mathrm{pico}) \mathrm{Cl}\right]$ and $\left[\left(\eta^{6}-p\right.\right.$ cym) $\mathrm{Ru}($ oxine $) \mathrm{Cl}]$ ) are cytotoxic towards both the A549 $\left(\mathrm{IC}_{50} 8-60 \mu \mathrm{M}\right)$ and $\mathrm{A} 2780$ $\left(\mathrm{IC}_{50} 4-15 \mu \mathrm{M}\right)$. $^{[69]}$ Interestingly the corresponding ruthenium complex $\left[\left(\eta^{6}-p\right.\right.$-cym $)$ $\mathrm{Ru}($ oxine $) \mathrm{Cl}]$ is inactive, ${ }^{[10]}$ indicating that not only the choice of ligand but also the choice of metal can influence the cytotoxicity. Os ${ }^{\mathrm{II}}$ complexes are generally believed to be more inert than their $\mathrm{Ru}^{\mathrm{II}}$ counterparts. ${ }^{\text {[70] }}$ Os ${ }^{\mathrm{II}}$ arenes containing ethylenediamine chelating ligands (e.g. the complex $\left(\left[\left(\eta^{6}-\right.\right.\right.$ bip)Os(en)Cl $]^{+}$were found to hydrolyze slowly $\left(\mathrm{t}_{1 / 2} c a .6 .3 \mathrm{~h}, 298 \mathrm{~K}\right)^{[64]}$ and those containing acac-type ligands hydrolyzed rapidly but formed inert hydroxo-bridged dimers under physiologically relevant conditions (vide supra) hence both sets of complexes were not cytotoxic towards A549 cancer cells. The N,O chelates display aqueous solution chemistry intermediate to $\mathrm{N}, \mathrm{N}$ and $\mathrm{O}, \mathrm{O}$ complexes with half lives for hydrolysis of [( $\eta^{6}$-bip)Os(pico) $\mathrm{Cl}]$ and $\left[\left(\eta^{6}-p\right.\right.$-cym $) \mathrm{Os}($ pico $\left.) \mathrm{Cl}\right]$ of 0.52 $\mathrm{h}$ and $0.20 \mathrm{~h}(298 \mathrm{~K}){ }^{[69]}$ Interactions of $\left[\left(\eta^{6}-p\right.\right.$-cym $) \mathrm{Os}($ pico $\left.) \mathrm{Cl}\right]$ with nucleotides showed binding to both $\mathrm{G}$ and $\mathrm{A}$, but with a strong preference for $\mathrm{G}$, and little or no reaction with $\mathrm{C}$ or $\mathrm{T}$. Under physiologically relevant concentrations $(\mu \mathrm{M})>40 \%$ of the osmium is bound to purine nucleobases and there is an increased kinetic stability of the 9-EtG adduct compared with 9-EtA and such kinetic stability may make $\mathrm{G}$ adducts less susceptible to repair compared to $\mathrm{A}$ adducts.

\section{Conclusions}

The chemistry of ruthenium(II)-arene complexes (as well as the heavier osmium(II)-arene analogues) is diverse and the choice of chelating ligand (YZ) and 'leaving group' (X) can influence the reactivity and hence the cytotoxicity of this class of complexes. We have shown that complexes such as $\left[\left(\eta^{6} \text {-arene }\right) \mathrm{Ru}(\mathrm{en}) \mathrm{Cl}\right]^{+}$ hydrolyse quickly in aqueous solution. The extent of hydrolysis is suppressed in high $\left[\mathrm{Cl}^{-}\right]$media as found extracellularly, and the aqua adducts have $\mathrm{pK}_{\mathrm{a}}$ values which allow the complex to exist as its 'active' $\mathrm{OH}_{2}$ form at physiological $\mathrm{pH}$ and interact with DNA bases. Subtle changes, e.g. changing the arene from $p$-cym to tha can influence the cytotoxicity since these extended arenes allow the complex to interact into DNA, and changes to the $\mathrm{X}$ group can render the complex inert to aquation but some can still retain cytotoxicity. Some en analogues have also been shown to exhibit in vivo anticancer activity and are thought to act in a manner distinct from cisplatin.

Other N,N chelating systems have been studied, and interestingly, when the ligand is 1,2-diaminobenzene, no cross resistance is observed in the 2780AD cell line, whereas this was not the case for the en analogues.

Changing the ligand to $\mathrm{O}, \mathrm{O}$ chelating ligands, for example $\left(\left[\left(\eta^{6}\right.\right.\right.$-arene $) \mathrm{Ru}(\mathrm{acac})$ $\mathrm{Cl}$ ] increases the hydrolysis rate and the $\mathrm{pK}_{\mathrm{a}}$ of the coordinated water and can change the base selectivity on account of steric interactions, and whilst some derivatives exhibit anticancer activity, deactivation via the hydroxo-bridged dimer $\left[\left(\eta^{6}\right.\right.$-arene $)$ $\mathrm{Ru}\left(\mu_{2}-\mathrm{OH}\right)_{3} \mathrm{Ru}\left(\eta^{6}\right.$-arene $\left.)\right]^{+}$is found to occur, and this was also observed for osmium analogues. N,O chelating ligands have also been investigated, and interestingly the Os complexes [( $\eta^{6}$-bip)Os(pico)Cl], $\left[\left(\eta^{6}-p-c y m\right) \mathrm{Os}(\mathrm{pico}) \mathrm{Cl}\right]$ and $\left[\left(\eta^{6}-p-c y m\right)\right.$ Os(oxine) $\mathrm{Cl}$ ] have been found to be active towards both A2780 and A549 cancer cell lines, whilst the ruthenium analogue $\left[\left(\eta^{6}-p\right.\right.$ cym) $\mathrm{Ru}$ (oxine) $\mathrm{Cl}$ ] was found to be inactive. This illustrates that the choice of metal as well as the choice of arene, chelating ligand and leaving group are all important in the design of this class of organometallic anticancer agents.

Received: July 30, 2007

[1] J. R. Durig, J. Danneman, W. D. Behnke, E. E. Mercer, Chem. Biol. Interact. 1976, 13, 287.

[2] M. J. Clarke, Met. Ions. Biol. Syst. 1980, 11, 231.

[3] C. G. Hartinger, S. Zorbas-Seifried, M. A. Jakupec, B. Kynast, H. Zorbas, B. K. Keppler, J. Inorg. Biochem. 2006, 100, 891.

[4] J. M. Rademaker-Lakhai, D. Van Den Bongard, D. Pluim, J. H. Beijnen, J. H. M. Schellens, Clin. Canc. Res. 2004, 10, 3717.

[5] M. J. Clarke, Coord. Chem. Rev. 2003 , 236, 209.

[6] G. Sava, S. Zorzet, T. Giraldi, G. Mestroni, G. Zassinovich, Eur. J. Cancer Clin. Oncol. 1984, 20, 841.
[7] G. Sava, S. Pacor, S. Zorzet, E. Alessio, G. Mestroni, Pharmacol. Res. 1989, 21, 617.

[8] G. Mestroni, E. Alessio, M. Calligaris, W. M. Attia, F. Quadrifoglio, S. Cauci, G. Sava, S. Zorzet, S. Pacor, et al., Progress in Clinical Biochemistry and Medicine 1989, 10, 71

[9] C. Scolaro, A. Bergamo, L. Brescacin, R. Delfino, M. Cocchietto, G. Laurenczy, T. J. Geldbach, G. Sava, P. J. Dyson, J. Med. Chem. 2005, 48, 4161.

[10] A. Habtemariam, M. Melchart, R. Fernandez, S. Parsons, I. D. H. Oswald, A. Parkin, F. P. A. Fabbiani, J. E. Davidson, A. Dawson, R. E. Aird, D. I. Jodrell, P. J. Sadler, J. Med. Chem. 2006, 49, 6858 .

[11] C. X. Zhang, S. J. Lippard, Curr. Opin. Chem. Biol. 2003, 7, 481.

[12] E. L. Muetterties, J. R. Bleeke, E. J. Wucherer, T. Albright, Chem. Rev. 1982, 82, 499.

[13] M. Stebler-Roethlisberger, W. Hummel, P. A. Pittet, H. B. Buergi, A. Ludi, A. E. Merbach, Inorg. Chem. 1988, 27, 1358.

[14] Y. Hung, W.-J. Kung, H. Taube, Inorg. Chem. 1981, 20, 457.

[15] S. W. Magennis, A. Habtemariam, O. Novakova, J. B. Henry, S. Meier, S. Parsons, I. D. H. Oswald, V. Brabec, P. J. Sadler, Inorg. Chem. 2007, 46, 5059.

[16] R. E. Morris, R. E. Aird, P. d. S. Murdoch, H. Chen, J. Cummings, N. D. Hughes, S. Parsons, A. Parkin, G. Boyd, D. I. Jodrell, P. J. Sadler, J. Med. Chem. 2001, 44, 3616.

[17] R. E. Aird, J. Cummings, A. A. Ritchie, M. Muir, R. E. Morris, H. Chen, P. J. Sadler, D. I. Jodrell, Br. J. Cancer 2002, 86, 1652.

[18] F. Wang, H. Chen, S. Parsons, I. D. H. Oswald, J. E. Davidson, P. J. Sadler, Chem. Eur. J. 2003, 9, 5810.

[19] W. J. Moore, 'Physical Chemistry', 4th ed., Longmans, London, 1962, p. 368.

[20] F. Wang, A. Habtemariam, E. P. L. van der Geer, R. Fernandez, M. Melchart, R. J. Deeth, R. Aird, S. Guichard, F. P. A. Fabbiani, P. Lozano-Casal, I. D. H. Oswald, D. I. Jodrell, S. Parsons, P. J. Sadler, Proc. Natl. Acad. Sci. USA 2005, 102 , 18269.

[21] M. T. Fairhurst, T. W. Swaddle, Inorg. Chem. 1979, 18, 3241.

[22] I. Rapaport, L. Helm, A. E. Merbach, P. Bernhard, A. Ludi, Inorg. Chem. 1988, 27, 873

[23] H. Chen, J. A. Parkinson, S. Parsons, R. A. Coxall, R. O. Gould, P. J. Sadler, J. Am. Chem. Soc. 2002, 124, 3064.

[24] C. Janiak, Dalton Trans 2000, 3885.

[25] H. Chen, J. A. Parkinson, R. E. Morris, P. J. Sadler, J. Am. Chem. Soc. 2003, 125, 173.

[26] H.-K. Liu, S. J. Berners-Price, F. Wang, J. A. Parkinson, J. Xu, J. Bella, P. J. Sadler, Angew. Chem., Int. Ed. 2006, 45, 8153.

[27] L. H.-K. Liu, F. Wang, J. A. Parkinson, J. Bella, P. J. Sadler, Chem. Eur. J. 2006, 5, 6151. 
[28] O. Novakova, H. Chen, O. Vrana, A. Rodger, P. J. Sadler, V. Brabec, Biochemistry 2003, 42, 11544.

[29] V. Brabec, M. Leng, Proc. Natl. Acad. Sci. USA 1993, 90, 5345.

[30] V. Brabec, V. Boudny, Z. Balcarova, Biochemistry 1994, 33, 1316.

[31] M. A. Lemaire, A. Schwartz, A. R. Rahmouni, M. Leng, Proc. Natl. Acad. Sci. USA 1991, 88, 1982.

[32] E. C. Long, J. K. Barton, Acc. Chem. Res. 1990, 23, 271

[33] R. Lyng, A. Rodger, B. Norden, Biopolymers 1991, 31, 1709.

[34] T. C Jenkins, in 'Drug-DNA Interaction Protocols', Ed. K. R. Fox, Humana Press Inc., Totowa, NJ. 1997, p. 195-218.

[35] M. V. Keck, S. J. Lippard, J. Am. Chem. Soc. 1992, 114, 3386.

[36] R. Zaludova, V. Kleinwachter, V. Brabec, Biophys. Chem. 1996, 60, 135.

[37] V. Brabec, V. Kleinwachter, J. L. Butour, N. P. Johnson, Biophys. Chem. 1990, 35, 129.

[38] O. Vrana, V. Kleinwachter, V. Brabec, Experientia 1984, 40, 446.

[39] O. Novakova, J. Kasparkova, V. Bursova, C. Hofr, M. Vojtiskova, H. Chen, P. J. Sadler, V. Brabec, Chemistry \& Biology 2005 , 12, 121.

[40] Y. Maeda, K. Nunomura, E. Ohtsubo, $J$. Mol. Biol. 1990, 215, 321.

[41] M. T. Bjorndal, D. K. Fygenson, Biopolymers 2002, 65, 40.

[42] E. R. Jamieson, S. J. Lippard, Chem. Rev. 1999, 99, 2467.

[43] J. Cummings, J. S. Macpherson, I. Meikle, J. F. Smyth, Biochem. Pharmacol. 1996, 52, 979.

[44] J. Cummings, I. Meikle, J. Macpherson, J. F. Smyth, Cancer Chemother. Pharmacol. 1995, 37, 103.

[45] R. L. Hayward, Q. C. Schornagel, R. Tente, J. S. Macpherson, R. E. Aird, S. Guichard, A. Habtemariam, P. Sadler, D. I. Jodrell, Cancer Chemother. Pharmacol. 2005, 55, 577.

[46] Y. N. V. Gopal, D. Jayaraju, A. K. Kondapi, Biochemistry 1999, 38, 4382

[47] S. M. Guichard, R. Else, E. Reid, B. Zeitlin, R. Aird, M. Muir, M. Dodds, H. Fiebig, P. J. Sadler, D. I. Jodrell, Biochem. Pharmacol. 2006, 71, 408.

[48] F. Wang, H. Chen, J. A. Parkinson, P. d. S. Murdoch, P. J. Sadler, Inorg. Chem. 2002, 41, 4509.

[49] I. W. McNae, K. Fishburne, A. Habtemariam, T. M. Hunter, M. Melchart, F. Wang, M. D. Walkinshaw, P. J. Sadler, Chem. Commun. 2004, 1786.
[50] F. Wang, J. Bella, J. A. Parkinson, P. J. Sadler, J. Biol. Inorg. Chem. 2005, 10, 147.

[51] F. Wang, J. Xu, A. Habtemariam, J. Bella, P. J. Sadler, J. Amer. Chem. Soc. 2005, 127, 17734.

[52] I. K. Adzamli, K. Libson, J. D. Lydon, R. C. Elder, E. Deutsch, Inorg. Chem. 1979, 18, 303.

[53] Y. K. Yan, M. Melchart, A. Habtemariam, A. F. A. Peacock, P. J. Sadler, J. Biol. Inorg. Chem. 2006, 11, 483.

[54] E. Steckhan, S. Herrmann, R. Ruppert, E. Dietz, M. Frede, E. Spika, Organometallics 1991, 10, 1568.

[55] H. Chen, J. A. Parkinson, O. Novakova, J. Bella, F. Wang, A. Dawson, R. Gould, S. Parsons, V. Brabec, P. J. Sadler, Proc. Natl. Acad. Sci. USA 2003, 100, 14623.

[56] J. Canivet, L. Karmazin-Brelot, G. SuessFink, J. Organomet. Chem. 2005, 690, 3202.

[57] S. J. Dougan, M. Melchart, A. Habtemariam, S. Parsons, P. J. Sadler, Inorg. Chem. 2006, $45,10882$.

[58] S. Goswami, A. R. Chakravarty, A. Chakravorty, Inorg. Chem. 1983, 22, 602.

[59] D. A. Freedman, D. E. Janzen, K. R. Mann, Inorg. Chem. 2001, 40, 6009.

[60] S. J. Dougan, A. Habtemariam, P. J. Sadler; unpublished results.

[61] S. J. Dougan, P. J. Sadler, unpublished results.

[62] R. Fernandez, M. Melchart, A. Habtemariam, S. Parsons, P. J. Sadler, Chem. Eur. J. 2004, 10, 5173 .

[63] T. Hasegawa, T. C. Lau, H. Taube, W. P. Schaefer, Inorg. Chem. 1991, 30, 2921.

[64] A. F. A. Peacock, A. Habtemariam, R. Fernandez, V. Walland, F. P. A. Fabbiani, S. Parsons, R. E. Aird, D. I. Jodrell, P. J. Sadler, J. Am. Chem. Soc. 2006, 128, 1739.

[65] A. F. A. Peacock, M. Melchart, R. J. Deeth, A. Habtemariam, S. Parsons, P. J. Sadler, Chem. Eur. J. 2007, 13, 2601.

[66] M. Melchart, A. Habtemariam, S. Parsons, S. A. Moggach, P. J. Sadler, Inorg. Chim. Acta 2006, 359, 3020.

[67] M. L. Tobe, J. Burgess. 'Inorganic Reaction Mechanisms', Longman, New York, 1999, p. 79

[68] W. S. Sheldrick, S. Heeb, Inorg. Chim. Acta 1990, 168, 93.

[69] A. F. A. Peacock, S. Parsons, P. J. Sadler, J. Am. Chem. Soc. 2007, 129, 3348.

[70] M. T. Ashby, S. S. Alguindigue, M. A. Khan, Organometallics 2000, 19, 547. 